
National Library

of Canada

Acquisitions and

Bibliographic Services Branch

395 Wellungton Street

Ottawa, Ontarto

K1A ON4
Bibliotheque nationale

du Canada

Direction des acquisitions et

des services bibliographiques

395. rue Wellinglon

Ottawa (Oniano)
NOTICE

The quality of this microform is heavily dependent upon the quality of the original thesis submitted for microfilming. Every effort has been made to ensure the highest quality of reproduction possible.

If pages are missing, contact the university which granted the degree.

Some pages may have indistinct print especially if the original pages were typed with a poor typewriter ribbon or if the university sent us an inferior photocopy.

Reproduction in full or in part of this microform is governed by the Canadian Copyright Act, R.S.C. 1970, c. C-30, and subsequent amendments.
AVIS

La qualité de cette microforme dépend grandement de la qualité de la thèse soumise au microfilmage. Nous avons tout fait pour assurer une qualité supérieure de reproduction.

S'il manque des payes, veuillez communiquer avec l'université qui a conféré le grade.

La qualité d'impression de certaines pages peut laisser à désirer, surtout si les pages originales ont été dactylographiées à l'aide d'un ruban usé ou si l'université nous a fait parvenir une photocopie de qualité inférieure.

La reproduction, même partielle, de cette microforme est soumise à la Loi canadienne sur le droit d'auteur, SRC 1970, c. C-30, et ses amendements subséquents. 
THE POSTMODERNIZATION OF SOCIAL PSYCHOLOGY

by

MARK LAJOIE, B.A.

\begin{abstract}
A Thesis submitted to
the Faculty of Graduate Studies and Research

in partial fulfilment of

the requirements for the degree of
\end{abstract}

Master of Arts

Department of Psychology

\author{
Carleton University \\ Ottawa, Ontario
}

December 1993 
The author has granted an irrevocable non-exclusive licence allowing the National Library of Canada to reproduce, loan, distribute or sell copies of his/her thesis by any means and in any form or format, making this thesis availakle to interested persons.
L'auteur a accordé une licence irrévocable et non exclusivé permettant a la Bibliothèque nationale du Canada de reproduire, prêter, distribuer ou vendre des copies de sa thèse de quelque manière et sous quelque forme que ce soit pour mettre des exemplaires de cette these à la disposition des personnes intéressées.

L'auteur conserve la propriété du droit d'auteur qui protège sa thèse. Ni la thèse ni des extraits substantiels de celle-ci ne doivent être imprimés ou autrement reproduits sans son autorisation. 
Nome

N1 e $k$

L o ive

Dissertation Abstracts International it arranged by brood, general subject categories. Please select the one subject which most neorly describes the content if your dissertation. Enter the corresponding four-digit code in the spaces provided.

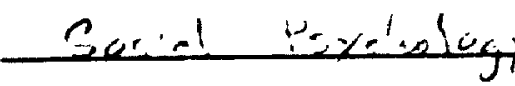

SUEVCT TEN

[वस्दाइए। U.M.I

sulver coos

\section{Subject Cologories}

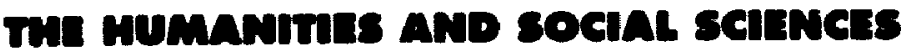

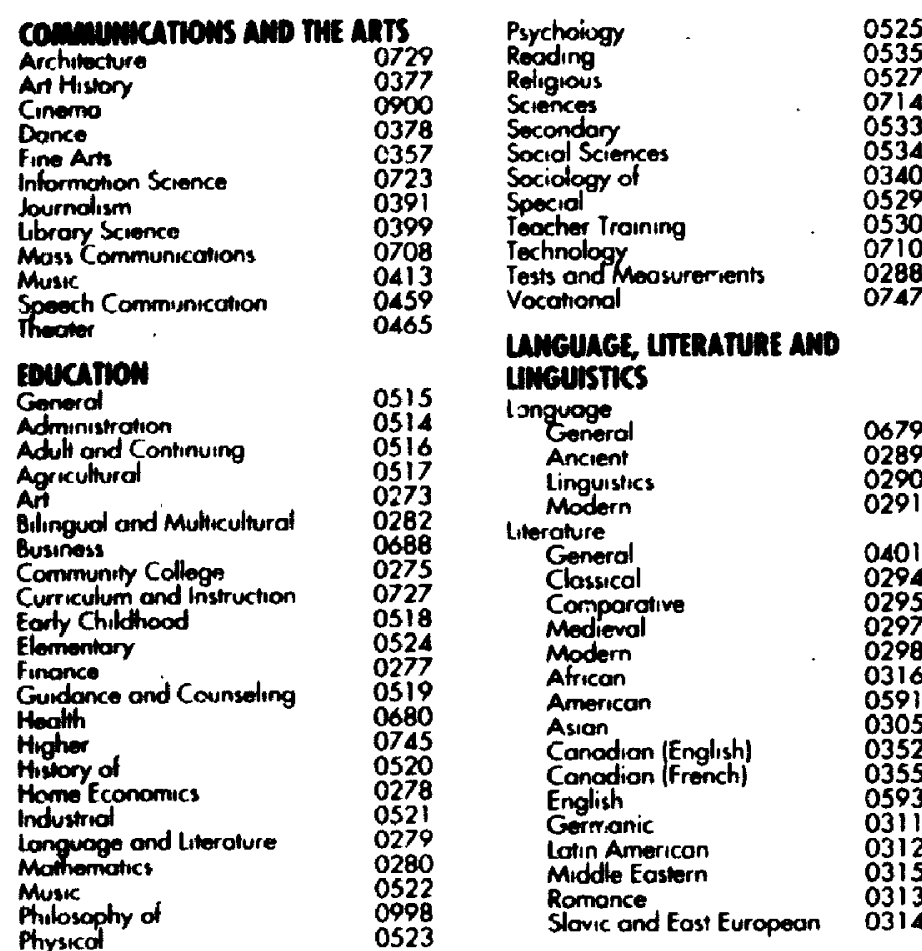

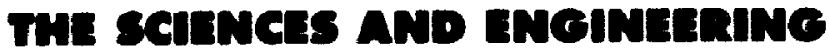

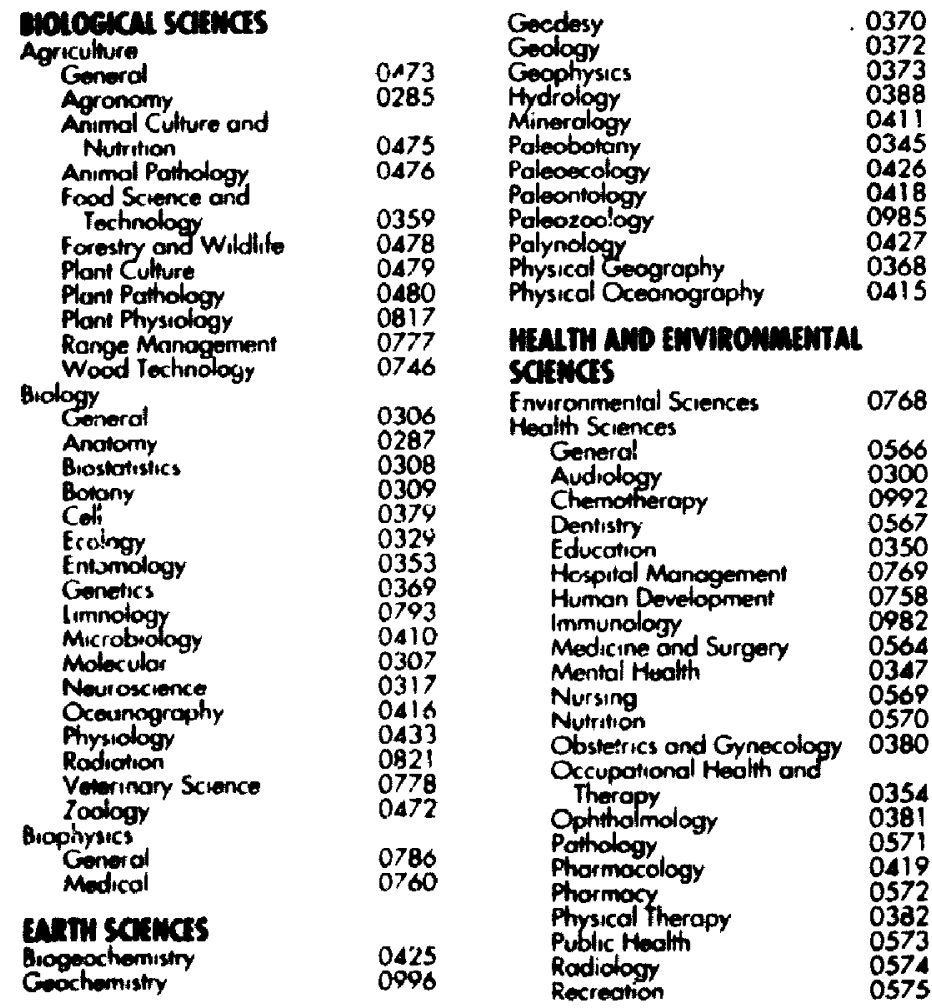

PHLLOSOPHY, REUGNON ANO THEOLOGY

Philosophy

Religion

General

Clergy

History of

Phitosophy of

Theology

sand satics

American Studies

Anthropology

Archaeology

Cultural

Business Administration

General.

Accounting

Bonking

Manogemen

Conodian Shudies

Economics

General

Agricultural

Commerce-Business

Finonce

Histor

Lobo

Theory

Folkore

Geogrophy

History

Generol

0422

0318

0321

0319

0320

0322
0469

0323

0324

0326

0327

0310

0272
0770

045.

0338

0385

0501

0501
0503

0505

0508

0509

(2)

0511

0358
0366
0351

0578

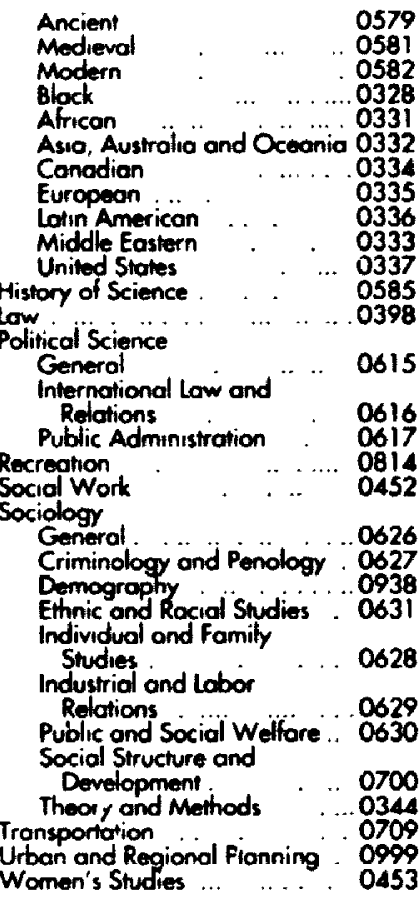

Speech Pothology

Home Economics

\section{Pursical sazncas}

Pure Sciences

Chernistry

Genergl

Anolytical

Biochemistry

Inorganic

Nucleor

Organic

Pharmaceutical

Physical

Polymer

Mothemolics

Physics

General

Acoustics

Astronomy and

Astrophysics.

Amospheric Science

Alomic

Electronics aind Electricity

Elemeniory Particles and

High Energy

Flusd and Plasmo

Molocular

Nucleor

Rodics

Solnd Stave

Statistics

Applied Sciences

Applied Mechanics

Computer Science
0460
0383

0386

0485

0749

0486
0487

0487

0738

0490

.0491

0494
0495

0495

0405

0605

0986

0606

0608

0607

0798
0759

0609

0610

0752

0611

0463

0346

\begin{tabular}{|c|c|c|}
\hline 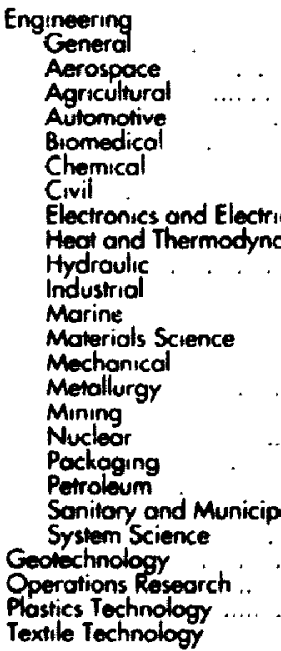 & $\begin{array}{l}\text { pol } \\
\cdots \\
\cdots \\
\cdots\end{array}$ & $\begin{array}{l}05 \\
05 \\
05 \\
07 \\
05 \\
07 \\
04 \\
07 \\
07 \\
09\end{array}$ \\
\hline $\begin{array}{l}\text { i } \\
\text { entol } \\
\text { tal } \\
y \\
\text { col } \\
\text { logy } \\
\text { trics }\end{array}$ & $\begin{array}{l}\cdot . \\
\cdots\end{array}$ & $\begin{array}{l}06 \\
06 \\
06 \\
06 \\
09 \\
03 \\
06\end{array}$ \\
\hline
\end{tabular}


The undersigned hereby recommend to

the Faculty of Graduate Studies and research acceptance of the thesis,

"THE POSTMODERNIZATION OF SOCIAL PSYCHOLOGY"

submitted by

MARK LAJOIE, B.A.

in partial fulfilment of the requirements for the degree of Master of Arts

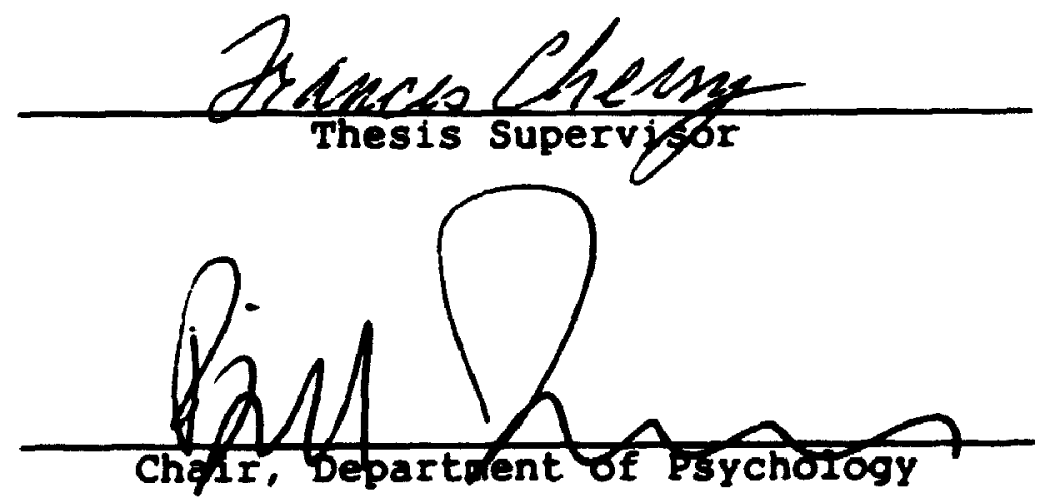

Carleton University

December 1993 
without the help and encouragment of a number of people this thesis would never have come together. Thanks to Fran Cherry for tireless advice, critical commentary and editing. Thanks to Cathy Borshuk for many debates, scrupulous editing, and trying to keep me honest. Thanks to Judith Kalin and Anna Paletta for engaging discussions about social psychology, postmodernism, and countless other things. Thanks to Judith Fredrick for giving me a job and for letting me see research in action. Thanks to my family for financial assistance.

Special thanks to Lisa Verdon for ALL of the above and more . 


\begin{abstract}
Postmodern social psychologists have connected the crisis in social psychology to postmodernism in general. This thesis argues that histnrically social psychology is a modern practice, and therefore at odds with postmodernism. Attempts by Kenneth Gergen and Ian Parker to modify social psychology in light of postmodernism are examined. It is argued that Gergen and Parker remain within the framework of social psychology. Michel Foucault's writings are used as examples of postmodern critique and the implications of these writings for social psychology are assessed.
\end{abstract}


Table of Contents

Page

Acceptance Form

Acknowledgements

Abstract

Table of contents

Introduction

Part I: Social Psychology as a Modern Discipline

The Beginnings of Social Psychology as a Modern Discipline (1890s-1920s)

Experimental Analyses of Individual and Social Behaviour (1920-1970)

The Crisis of Confidence and Post-Experimental Social Psychology

Part II: Postmodernism; What is it?

Aesthetic Postmodernism

Sociological Postmodernism

General Postmodern Theory

Part III: Postmodernism and Social Psychology

Gergen's Postmodernism

Parker's Ambivalent Postmodernism

Part IV: Foucault and Social Psychology: Towards a Political Social Psychology

The Individual and the Social in Political context 
The Postmodernization of Social Psychology

The notion of postmodernism has gained a great deal of currency in the past decade. No longer confined to literary or architectural enclaves, it has extended to a number of disparate fields, including philosophy (Baynes, Bohman \& McCarthy, 1987), sociology (Cheal, 1990; Bauman, 1988), geography (Harvey, 1989; Soja, 1989), law (Carty \& Mair, 1990), and even management (Salaman \& Butler, 1990; Letishe, 1990). Only recently has the term entered into psychological debate, via the field of socia! psychology. While the amount of psychological literature on the subject is relatively meagre, what exists has prompted the authors of a recently published historical social psychology textbook to end their analysis with a discussion of social psychology in the 'postmodern age'. (Collier, Minton \& Reynolds, 1991).

For over twenty years, social psychologists have been writing about the crisis in the field. One aspect of the growing critical literature is the linkage of social psychology's specific crisis to the more general crisis in modern culture and society (cf. Sampson, 1989; Gergen, 1990; Hare-Mustin and Maracek, 1988). It is this linkage which is the subject of this thesis. In contrast to the above mentioned social psychologists who see the relation of these crises as unproblematic, I will argue that the manner in which tney use postmodernism remains consistent with traditional social psychological concepts. 
The idea of postmodernism is itself rather vague, owing in part to the lack of agreement among what scholars define as modern (Baudrillard, 1987; Berman, 1988; Habermas, 1981; Giddens, 1981)

and whether or not they support a revision of modernism (Habermas 1981; Berman, 1988) or an abandonment of it (Baudrillard, 1987; Kroker \& Cook, 1986; Lyotard 1984). What is certain is that the concept has crept into a number of places, ranging from academic disciplines to the mass media. As postmodernism has spread to many disciplines, the range of meanings imputed to the term has increased, as has the cast of writers, performers and artists included in the growing pantheon of 'postmodernists'. While the use of general terms to refer to groups of individuals is not inherently problematic, there is usually some degree of affinity between the members comprising groups. What are the affinities that link the postmodernist? As Butler (1992) asks,

Who are these postmodernists? Is it a name one takes for oneself, or is it more often a name that one is called if and when one offers a critique of the subject, a discursive analysis, or questions the integrity or coherence of totalizing social descriptions? (p.3)

If the latter is the case, then it is true that many social psychologists have indeed gone postmodern.

Butler argues that the term postmodernism is often conflated with poststructuralism as well as deconstructionism, French feminism, Lacanian psychoanalysis, Foucaultian 
Postmodern Social Psychology 3

analysis, Rorty's conversationalism and cultural studies. According to Butler (1992)

On this side of the Atlantic and in recent discourse, the terms 'postmodernism' or 'poststructuralism' settle the differences ...ong these positions in a single stroke, providing a substantive, a noun, that includes those positions as so many of its modalities or permutations.(p.4)

The use of the generalizing rubric 'postmodernism', seems to lend greater support to specific assertions by individual postmodernists, and also allows for the selective use of their works by others, while maintaining, or implying a sense of coherence. Thus, Baudrillard's work may be used as an exemplar of postmodernism, after which his claims can be imputed to the entire group.

Postmodernism is currently represented as a general term which implies a growing convergence of theoretical sensibilities, even if the differences among the various projects which the term subsumes are obscured or considered superficial. Butler asks,

Is the effort to colonize and domesticate these theories under the sign of the same, to group them synthetically and masterfully under a single rubric, a simple refusal to grant the specificity of these positions, an excuse not to read, and not to read closely? (Butler 1992, P.5)

Butler's question could be appropriately asked in social psychological circles.

My intent in the thesis is to chart the development of 
postmodernism in social psychology. I will argue that social psychologists employing the term 'postmodernism' fail to explain it adequately, or to engage with the specific problems raised by the various thinkers comprising the postmodernist pantheon, but rather make selective uses of the works of the latter. In order to avoid the problem of generalizing across specific works, I will limit my analysis to the works of two social psychologists who have contributed to the 'postmodernization' of social psychology: Kenneth Gergen and Ian Parker.

My central thesis is that the current appropriation of the rhetoric of postmodernism by social psychologists does not challenge the basic premises of the discipline of social psychology. Through a selective reading of the 'postmodernists', social psychologists rob those writers of insights and arguments which have critical potential for social psychology. In effect, appropriating the rhetoric of postmodernism has served to insulate critical social psychologists from works which call the very basis of social psychological inquiry into question. I will argue that the basic tension which social psychology aims at resolving, the relation between the individual and the social, is a product of modern thought and practices, and therefore cannot persist in its current form in the face of consistent postmodern critique.

Through historlcal analysis of early social 
psychologists, I will make the claim that social psychology has developed within the framework of a relationship between the individual and the social. I will then turn to an examination of postmodernism, and attempt to provide a clearer account of what the jea entails, and how it has been selectively introduced into social psychology through a comparison of Gergen and Parker's writings. Finally, I will examine the work of Michel Foucault. who is often cited as an exemplar of postmodernism, and the questions his work raises for the theory and practice of social psychology. 
Part I: Social Psychology as a Modern Discipline

While I realize that periodizing social psychology, or any discipline for that matter, involves a certain degree of arbitrariness, I will divide my account of the history of the discipline into three periods, marked off by a recurring crisis. The first period marks the 'beginnings' of the discipline of social psychology during the 1890 s ending with a crisis in the 1920s;, the second period from the 1920s until the second crisis in the 1970s; the third period from the 1970 s to the present. These crises mark shifis in the direction of social psychological inquiry and the practices employed in the production of social psychological knowledge about individuals and their social worlds.

The Bejinnings of Social Psychology (1890s-1920s)

The first period extends into the murky domain of the pre-history of the discipline. To pose the question of a discipline in terms of foundations or origins is a troublesome practice, given the diverse forces and events which intersect to form a domain of knowledge and sets of practices aimed at deriving such knowledge. Indeed, to claim descent from a single point of origin is to emphasize one set of historical forces at the expense of obscuring others. Yet, Edward Ross and William MCDougall's textbooks of social psychology, both published in 1908 are often cited as the earliest attempts to 
define the discipline as a coherent area of inquiry distinct from other disciplines, specifically psychology and sociology.

Ross, an American sociologist, drew upon the works of French social theorists Gabriel Tarde and Gustav Le Bon who were concerned with crowd phenomena. Ac rording to Ross (1908), social psychology

studies the psychic planes and currents that come into existence among men in consequence of their association. It seeks to understand and account for those uniformities in feeling, belief, or volition - and hence in action - which are due to interactions of human beings, ie., to social causes. (p.1)

The emphasis on uniformities draws on Ross' insight that if individual 'endowment' were solely the product of blology, people would be much more dissimilar than they in fact are. He argued,

The aligning power of association triumphs over diversity of temperament and experience.... The individuality each has received from the hand of nature is largely effaced, and we find people gathered into great planes of uniformity.(p.1)

Ross distinguished between planes and currents of social existence. The planes are those 'agreements in which men rest, such as languages, religions, and cultures'(p.2). The distinguishing mark of a plane was that it was a basls of uniformity among individuals which was due to mental processes. Currents refer to any phenomenon which 'bears 
people along for a time and then ceases' (p.1-2). The paradigmatic example of a current was the crowd, although fashion and customs may also be described thus. Social psychology, Ross argued, was concerned with both planes and currents.

According to Ross social psychology differed from sociology in that the latter considers groups and structures, instead of planes and currents. There were certain types of phenomena that social psychology did not take into consideration. First, Ross excluded, "[n]on-psychic parallelism among human beings ... or psychic parallelism that result therefrom." (p.2) Ross cited epidemics as examples of 'non-psychic parallelism'. An epidemic produces similar physical effect, thus producing uniformities, however it is not the product of mental contacts or interactions.

Secondly, he excluded "[u]niformities among people that are produced by the direct action of a common physical environment $\ldots$ or subjection to similar conditions of life..." (p.2) Thus the effects of physical surroundings or similar ilfestyles would not fall into Ross's definition of social psychology. Finally, "[u]niformities arising directly or indirectly out of race endowment." (p.3) were ex luded. This third point referred back to his original contention that if the way people are were blologically produced, one would expect to see much less uniformity than one sees. Social psychology, he concluded, "deals only with ul iformities jue to 
social causes, i.e., to mental contacts or mental interactions..." (p.3).

Ross thus excluded from social psychological examination, material and physiological causes thereby defining the social as a purely 'mental' concept. The social, as Ross construed it, is a set of relations between people as if they were bereft of bodies and material constraints. As Ross stated the matter, the aggregation of numerous individuals does not make a relation social, but rather, "[1]t is social only in so far as it arises out of the interplay of minds." (p.3) He used the term 'interpsychology' to designate this relation.

For Ross, social psychology served an emancipatory aim, specifically by bringing to light those processes of psychological formation from which the individual had been alienated. According to Ross,

by demonstrating everywhere in our lives the unsuspected presence of social factors, social psychology spurs us to push on and build up a genuine individuality, to become a voice, not an echo, a person and not a parrot.... Only by emancipation from the spell of numbers and age and social eminence and personality can ciphers become unequal integers. (p.4)

Social psychology was therefore committed to the notion of individual emancipation, as well as the understanding of the processes which hinder this development. Social psychology, he argued,

seeks to enlarge our knowledge of the individual by ascertaining how much of his mental content and 
Postmodern Social Psychology 10

choice is derived from his social surroundings. (p.4)

Ross implied that the individual precedes the social, and therefore it was the task of social psychology to comprehend the nature of this interaction.

According to Ross, what distinguished social psychology from the older wundtian tradition of introspective individual psychology is the recognition that the contents of the mind could not be simply elaborations of mental phenomena, but rather are collectively produced. He described two main forms of collectivites, which he called the crowd and the public. Both stood in opposition to the individual. The crowd, or as he also called it, the throng, is formed by the physical proximity of a number of individuals. Publics were less physically rooted, and more dependent on media. Both operated according to a process of interstimulation and suggestion, usually from a leader. Both, however, were antithetical to individuality. As Ross summarized

"[i]n the dense throng individuality wilts and droops." (p.54) He argued the crowd is essentially emotional, unstable, credulous, irrational, and immoral. However, "[t]he Rules of order [capitalization in the original] save the deliberative assembly from degenerating into the crowd." (p.54)

According to Ross, the best defence against the excesses of the crowd were Rules of Order and the fortification of individuality. Ross' discussion of the crowd had a particular 
Postmodern Social Psychology 11

aim, specifically the development of what he called prophylactics against the mob mind, techniques for ensuring the protection of the individual against the crowd or the public.

Clearly, for Ross, the individual was separate and set against the social. While dependent upon individuals, the social was functionally autonomous, in the sense that social phenomena existed which went beyond the mere aggregation of individuals. The crowd, a form of disorganized interrelation, posed a threat to individuality, and, by extension, the social order. The promotion of the individual was a necessary element for the persistence of the social.

William McDougall, a British psychologist who was influenced by Spencer and Galton, argued that social phenomena were the product of 'social instincts'. Wh1le McDougall's text purports to be concerned with social psychology, it actually devotes little space to that subject. The work can in fact be read as a conventional piece of general psychology. McDougall himself agreed, and felt that this work was more in the nature of a prolegomenon to the foundation of a social psychology. (cf. Collier, et al, 1991). McDougall (1926) argued that psychology, as the

1 Among the measures Ross suggests are 1) higher education, 2) sound knowledge of body mind and society, 3) familiarity with the classics, 4) the influence of sane teachers, 5) avoidance of sensational media, 6) sports, 7) country life, 8) a well knit family, 9) ownership of property, 10) participation in volunteer organizations, 11 ) inteliectual self-possession, 12 ) self-respect and neighbour love, and 13) vital religion. (p.84-91) 
science which claims to formulate the body of ascertained truths about the constitution and work of the mind...(p.1)

was an essential foundation for the social sciences. Critical of the lack of attention paid to psychology by the other social sciences, he argued that social psychology served to 'make good the deficiencies' (p.2) that this oversight produced.

The task of social psychology, according to McDougall was

...to show how, given the native propensities and capacities of the individual human mind, all the complex mental life of societies is shaped by them and in turn reacts upon the course of their development and operation in the individual. (p.18)

In other words, social psychology seeks to explicate the dynamic relation between the individual and the social where the latter is no more than the aggregate of the former.

According to McDougall,

the fundamental problem of social psychology is the moralization of the individual by the society into which he is born as a creature in which the nonmoral and purely egoistic tendencies are much stronger than any altruistic tendencies. (p.18)

Moralization is here used in a sense similar to the term socialization, albeit with a much more ethical tone. What is important to note is the distinction McDougall makes between the pre-social human being and the social order into which that being is more or less successfully integrated. 
Postmodern Social Psychology 13

Both Ross and McDougall maintain the distinction between a pre-given individual and the social, both see social forces at work on the innate characteristics of individuals, and both understand the social to consist of mental phenomena. Where they diverge is the different emphasis given to the two terms of the individual-social dichotomy. According to Ross, social psychology is concerned with determining the extent to which social factors contribute to individual psychological phenomena. McDougall, on the orher hand, sought to develop a psychological foundation for the study of social phenomena. Social psychology during the period following the publication of Ross and McDougall's manifestos was largely practised as a branch of sociology, by sociologists. This was to change throughout the 1920's however, as social psychology shifted more in the direction of psychology.

Experimental Analyses of Individual Social Behaviour $(1920-1970)$

Much of the wricings of the 1920 s and 1930 s was devoted to the proper scope and subject matter of social psychology (Collier, et al. 1991). The practice of social psychology shifted toward the direction of general psychology accompanied by the psychological method of choice: experimentation. In social psychology, the impetus towards experimentalism was provided by the writings of Floyd Allport. Historian, D.J. Murphy (1988) claimed that, "McDougall gave social psychology 
Postmodern Social Psychology 14 an identity, but it was F.H. Allport who gave it a status." (p. 287)

Allport's experimentalism can be seen as an effort to resolve a crisis of objectivity in social psychology which occurred in the 1920's (Pychyl, 1988). In part, the crisis of objectivity was the result of dissatifaction on the part of psychologically inclined social psychologists with "vague, non-verifiable sociological theories"(Collier, et al, 1991 , p.86). Social psychology, in other words, had to demonstrate that it produced objective, demonstrable knowledge. As social psychologists were seeking legitimacy within the larger discipline of psychology, they turned to the experimentalism, behaviourism and scientism that had been developing in general psychology.

The problems experimentation aimed to resolve concerned the nature of social psychological knowledge, as well as the demarcation of a boundary with the discipline of sociology. Allport (1924) argued that social psychology was the experimental study of Individual behaviours which comprise

the stimulations and reactions arising between the individual and the social portion of his environment; that is, between the indfvidual and his fellows. (p.3)

Tracing the development of social psychology to Triplett's (1898) 'classic' experiment on social facilitation, Allport claimed that only through experimentation could social psychology provide cumulative and increasingly accurate 
Postmodern Social Psychology 15

scientific knowledge of human social behaviour. The experimental method proposed to determine universal principles of human behaviour, from which the specifics of individual actions could be deduced and comprehended.

Murphy, Murphy and Newcomb (1937) argued that experimentation, while not the only criterion of validity in social psychological research, was ultimately the best:

Experiment in these cases is the crowning touch, the technical perfection of the anjlysis. It must be emphasized, however, that the experimental method in all these cases comes late. It comes after the problem has been defined and its salient characteristics so well formulated that we know what can be controlled and measured.(p.14)

Like physics, experimentation plays a crucial role because 'clear questions have been put to nature' (p.14)

Allport's promotion of experimentation must also be seen as a tactical device for the promotion of a psychological social psychology, distinct from sociology. His version of social psychology produced a number of exclusions, among them studies of group processes and applied research. Applied research, which was guided by practical concerns, could not be entirely objective, and therefore scientific. According to Allport the group was simply the sum of the individuals comprising it, group processes could therefore be reduced to individual processes. Allport was committed to reducing social processes to individual processes:

... I believe that only within the individual can we 
find the behaviour mechanisms and the consciousness which are fundamental in the interaction between individuals. (Allport, 1920, p.vi)

Social behaviour was conceptualized in an abstract sense to refer to interactions between organisms, therefore allowing for comparative studies of social interaction. Murphy et al., asked

If chasing and pursuing among human beings is a social fact, why is it not when it occurs in amoeba? If the formation of human groups with mutual interstimulation is a social fact, why is not the formation of groups of protozoa likewise a social fact? (p.19)

Although they never answer the question, they conclude by asserting, "[t]he social is literally an aspect of the biological (italics in original)."(p.19) The social is thus naturalized as an innate propensity within individuals and the continuum between social and biological science is taken as part of a scientific social psychology.

There were many dissenting opinions about the proper scope of social psychology. Newcomb (1951), for example, was dissatisfied with both sociological and psychological approaches. He argued that the problem with psychological social psychology was that its practitioners

[took] no systematic account of the facts of the social environment in which human organisms live.(p.7)

On the other hand, sociological social psychologists were faulted for 
assuming that human organisms are virtually empty receptacles into which culture is simply poured.(p.8)

Newcomb's essay argued for the resolution of the tensions between the two tendencies, although this never occurred.

If we look at other definitions provided by the psychological branch the tensions becomes evident and we can speculate more on why they are never resolved. According to Klineberg (1940),

Social psychology may be defined as the scientific study of the behaviour of the individual as related to other individuals. It is concerned with the individual in the group situation. (p.3)

Murphy, et al (1937) argue

Social psychology studies individuals in their interaction when the fact of their interaction is of central interest, and when the analysis of impersonal stimuli and the fact of historical determination are not matters of primary concern. (p.24)

Gordon Allport (1954) provided what has become the conventional definition of social psychology:

social psychologists regard their discipline as an attempt to understand and explain how the thought, feeling, and behaviour of individuals are influenced by the actual, imagined, or implied presence of other human beings.(p.5)

The above definitions, which could be found in almost any social psychological textbook from the 1930's onward, define the parameters of these concepts. Analyticaily the term social 
Postmodern Social Psychology 18

psychology contains two concepts, psychology and the social. Psychology is the study of the behaviours, thoughts and feelings of individuals, while the social dimension is defined as the interaction between individual human beings. As Murphy, el al, (1937) indicated, impersonal stimuli and historical determination are not the subject of social psychological investigation. Social psychology tries to understand the individual in terms of social relations. In other words, social psychology, at least according to psychologically inclined practitioners, aims at articulating the relation between individuals and the social, but does so at the cost of obscuring social complexity.

On the other side of the division of labour, sociologists have provided their own definitions of social psychology. Theodorson and Theodorson's (1969) A Modern Dictionary of sociology defines social psychology as

The branch of sociology that deals with the study of individual behaviour as explained in terms of social factors and with the study of group structure in terms of the behaviour of individuals who comprise it. It is concerned with the study of the individual as a unit in a social group, and emphasizes the analysis of an individual's statuses and roles, and the relationship of an individual's statuses and roles to the total pattern of statuses and roles of a group or community.(p.392)

According to Inkeles (1966)

From a sociological perspective social psychology includes any study of social processes which systematically considers how the psychological properties of every man, or the personality 
dispositions of particular men, acting in a situation, influence the outcome of social processes. (p.23)

The definition points to an emphasis on the effects of individuals on the social, as well as the place of individuals within the social.

A number of sociological texts discuss the differences in approach. 'Psychologists', John Hewitt (1979) points out 'Are mainly interested in behaviour at an individual level'. He adds,

Even though their version of social psychology to some extent introduces social and cultural factors. it is basically preoccupied with what individuals do and with the forces that influence individual behaviour, attitudes, and subjective experiences. Socinlogists, on the other hand, tend to be more concerned with the description and explanation of patterns of conduct among larger aggregates of people - groups, social classes, and sometime whole societies. Thus even when sociologists introduce a social-psychological perspective, bringing individuals and their experiences into the explanation of these patterns they are still basically preoccupied with the patterns themselves. (p. 2)

It seems that both sociologists and psychologists are agreed that social psychology aims at articulating the processes that mediate the social and the individual, with the sociologically minded opting for aggregate social patterns as a basis of analysis, and the psychologically oriented looking at individuals. While the differences may seem clear and necessary, they reflect the historical divisions of labour that developed in the field from the 1920 s onward. 
Postmodern Social Psychology 20

It could be argued that psychological social psychology's turn towards physical science models served, for a while at least, to displace the problems inherent in the discipline. It is the case that throughout the post-war period most of the studies published in the main journals were experimental (Collier et al., 1991) However, there were continual questions raised about objectivity in sorial research even if they were not in the foreground. F. Allport's work in the 1920 s and subsequent treatises on experimentation in social psychology (Aronson \& Carlsmith, 1954) set the agenda for the field in a way that masked dissent. While Allport's work seemed to resolve the tensions between the individual and the social by reducing the latter to the former, these repressed tensions returned in the form of the crisis of the 1970 s.

The Crisis of Confidence and Post-Experimental

Social Psychology.

In the early 1970s Kenneth Gergen (1972) provoked a significant debate over the nature of social psychological inquiry. Arguing that social interaction was historically contingent, Gergen claimed that social psychology could not provide immutable laws of social behaviour (Gergen, 1972). Rather than being a scientific discipline, Gergen argued that social psychology was an historical mode of inquiry.

The crisis of the 1970 s marks the transition from the second to the third period. Although not all social 
Postmodern Social Psychology 21

psychologists would agree (Jones, 1985), the 1970s did produce a space in which the practice of the discipline, a practice formed by experimental methods and Allport's attempt to resolve the crisis of objectivity, was brought under critical analysis. In effect, this crisis tried to undo what Allport had wrought. The main features of Allport's social psychology, including the experimental method, behaviorism, the segregation of sociological and psychological branches of the field, and the privileging of 'scientific' over applied research were all subject to question. It is dubbed the crisis of confidence (Elms 1975) in that it expresses the lack of confidence in the solutions the earlier crisis of the 1920 s failed to resolve through the version of social psychology as an experimental science divorced from sociology.

Responses to the crisis of the 1970 s diverged greatly. On the one hand, a number of researchers argued in favour of more rigorous methods to counter the problems posed by experimental biases, as well as greater application of the methods of social psychology outside of the laboratory. In contrast, a second group of researchers argued in favour of interpretive methods, an abandonment of both experimentation and the search for invariant laws of human behaviour. It is within the context of this latter line of development that the encounter with postmodernism occurs.

The extent of Gergen's critique cannol be underestimated. In effect, Gergen subverted the central tenet of 
Postmodern Social Psychology 22 the conventions of social psychology which developed from Floyd Allport's work. Allport's claim that as an experimental science psychology could provide increasingly accurate accounts of social behaviour was based on the, concept of universal laws. If social interaction changed over time, then such laws could not be derived. Changes in social behaviour were better viewed as the product of hiscorical change, thus allying social psychology with the social, rather than the natural sciences.

Gergen's work served to erode the barrier built between sociological social psychology and psychological social psychology. The social sciences had long been concerned with the processes of social change, thus social psycho'ogists would have more to gain from sociologists and historians than physicists, biologists, and experimental psychologists. While Gergen's work did not eliminate the barrier, at least it turned a brick wall into a picket fence. It meant that psychological social psychologist could talk to their sociological neighbours.

Gergen's work also brought the question of applied social psychology into focus. Scientific social psychology viewed its applied relative as a country cousin; related, but less sophisticated. Being applied meant that one was subservient to specific interests, contrary to the practice of disinterested observation. The promise of science was the progressive accumulation of knowledge which would ultimately benefit 
mankind

If however, social psychologists could not provide immutable truths, at the very least they could provide an understanding of existing circumstances. Realizing that the benefits of social psychological knowledge could only be realized in the short term, Gergen argued that researchers should deal with contemporary social problems. Thus the interests of science would be replaced by concern for the contemporary social good.

What an historical overview of these three periods in social psychology reveals is that from the 1890 s to the present, there is an ongoing debate over the definition of the field in terms of its objects of study - the individual and the social, and their relationship to one another. At times the definitional tensions are mild; at other times there are full blown crises. Social psychological proponents of postmodernism see it as a means of cesolving social psychology's chronic tension. The following section will examine whether postmodernism lives up to this claim, or whether it merely preserves the tension. 
Part II: Postmodernism: What Is It?

Defining postmodernism is a notoriously difficult task, for reasons which have more to do with the history of the concept than the complexity of the ideas generally associated with the term. As literary critic Ihab Hassan (1985) pithily proclaims,

In the last two decades the word postmodernism has shifted from awkward neologism to derelict cliché without ever attaining the dignity of concept. (p.119)

However, as Hassan would admit, postmodernism has not suffered from a lack of conceptualization, but rather a surfeit. Nor have there been any lack of 'postmodernists'. Hassan for example, devotes a full page to enumerating them in an essay concerning 'postmodern culture' (Hassan, 1985). If the label is in fact conceptually vacant, it does carry a high degree of prestige. He asks:

is postmodernism an honorific term, used insidiously to valorize writers, however disparate, whom we otherwise esteem, to hail trends, however discordarit, which we somehow approve? (p.122)

In order to avoid this tendency I will discuss postmodernism in the contexts in which it arose, since, as I will attempt to demonstrate, there is good reason to doubt that postmodernism is a coherent or unified theoretical project.

Postmodernism has a relatively long history outside of 
Postmodern Social Psychology 25

social psychology. The term can be traced to the Spanish word 'postmodernismo', coined by Latin American literary critic Fredrico de onis (Koehler, 1977). Although historian Arthur Toynbee is often credited with the first use of the english term 'postmodernism' in 1947, the earliest consistent use in North America appears in literary criticism (Hassan, 1977) and architecture (Jencks, 1977) during the 1960s and 70s. It is in this context that the concept of postmodernism developed and attained some degree of currency.

During the late 1970s and early 1980 s debates about postmodernism became linked to currents within French thought which have since been labelled 'post-structuralism' . According to literary critic Andreas Huyssen, (1990)

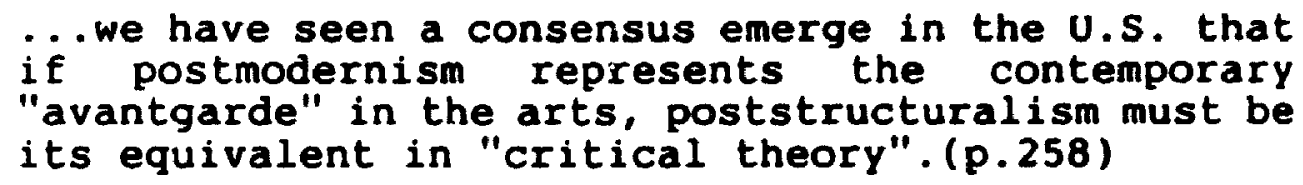

The link seems to be that the 'poststructuralists' offer a critical theory of modernity, or at least of modern social formations and philosophy. It has since become standard practice to reduce postmodernism to poststructuralism, and to present the thinkers subsumed under the latter label, including Jacques Derrida, Roland Barthes, Michel Foucault, Jean-Francois Lyotard and Jean Baudrillard, as the main proponents of postmodernism.

By the time psychologists encountered postmodernism in the late 1980s the distinction between it and 
Postmodern Social Psychology 26

poststructuralism had blurred considerably. The 'new paradigm' theorists (Shotter \& Gergen, 1989; Parker \& Shotter, 1990) began to draw on the developing sociological theory that resulted from this blurring and to move some of the ideas into social psychological debate.

In a lecture designed to introduce postmodernism to the general public, San Francisco bookseller Michael Rosenthal (1993) offered a useful definition of the term:

Postmodern critique begins with a scepticism towards the metanarrative of reason, by fccusing on the issue of power - the way in which 'reason' is imposed on everyday life. It reminds us that the constructions of rationality and order that inform the modern world have always been heavily implicated in practices of domination.... The critique then extends to all metanarratives that offer transcendental guarantees or construct totalizing opposition - all claims to pure, fixed categories of thinking and being. (pp. 94-95)

Thus, postmodern critique is concerned with the means by which metanarratives, such as Reason or Catholicism, or Liberalism, are used to explain other narratives. It also rejects any claim to a position outside of narrative which would establish the validity of a specific metanarrative over and above all others.

This rather vague definition is typical of most accounts of postmodernism, however, as I have argued, postmodernism is by no means unified theoretically. Following Messmer (1985) and Featherstone (1988), I will discuss postmodernism in the context of aesthetics, sociology and general theory. 


\title{
Aesthetic Postmodernism
}

From the beginning postmodernism has resisted definition, as Village Voice columnist John Perrault argued,

Postmodernism is not a particular style, but a cluster of attempts to go beyond modernism. In some cases this means a 'revival' of art styles 'wiped' out by modernism. In others it means anti-object or what have you. (cited in Koehler, 1977).

According to architect Charles Jencks (1977),

\begin{abstract}
Post-modernism is a portmanteau concept covering several approaches to architecture that have evolved from Modernism. As this hybrid term suggests, it's architects are still influenced by Modernism - in part because of their training and in part because of the impossibility of ignoring Modern methods of construction - and yet they have added other languages to it. A Post-modern building is doubly coded - part Modern and part something else: vernacular, revivalist, local, commercial, metaphorical, or contextual.(p.111)
\end{abstract}

Modernism therefore is not strictly equated with a period, but rather with a particular way of doing art. The revival of 'lost traditions', which developed alongside modernism, is a way of getting outside of modernism, as is the development of objects which subvert modern aesthetic forms. Aesthetic postmodernists attempt to create works which are no longer modern.

Postmodernism in the arts clearly involves a relation to a relatively well-established modern tradition. In literature Modernism involves formal conventions, including characterization and linear narrative, as well as distinctive 
Postmodern Social Psychology 28

relations between author, text and reader. Architectural Modernism involves principles of design, among them minimalist, International style (buildings designed to be invariant across locale), and a mechanistic aesthetics. According to Featherstone (1988)

[ $t$ ] he basic features of modernism can be summarized as: an aesthetic self-consciousness and reflexiveness; a rejection of narrative structure in favour of simultaneity and montage; an exploration of the paradoxical, ambiguous and uncertain open-ended nature of reality; and a rejection of the notion of an integrated personality in favour of an emphasis upon the destructured, dehumanized subject.(p.202)

Featherstone (1988) argues that aesthetic postmodernism is associated with the following features,

the effacement of the boundary between art and everyday life; the collapse of the hierarchical distinction between high and mass/popular culture; a stylistic promiscuity favouring eclecticism and the mixing of codes; parody, pastiche, irony, playfulness, and the celebration of the surface 'deathlessness' of culture; the decline of the originality /genius of the artistic producer; and the assumption that art can only be repetitious.(p.203)

For the most part, aesthetic postmodernism is critical of the elitism characteristic of so much modern art, as well as the privilege of the artist in the production of the aesthetic object. It is also critical of attempts to produce definitive works, those which claim universality of content, or to express something essential to the 'human condition'. In this way, aesthetic modernism is connected to the criticisms of 
Postmodern Social Psycrology 29

social psychology that are heard in the 1970 s.

\section{Sociological Postmodernism}

A distinct sociological form of postmodernism emerged in America during the late 1960s, based on a recognition of the impact of innovations in communication, information and energy technologies (Etzioni, 1968). Bell (1976) argued that the counterculture of the 1960 s enacted the revolts of aesthetic modernism in everyday life, thus leading to the end of the modern age, typified by a bourgeois world view. Unlike postmodernism in the arts, which relates to modernism as an aesthetic style, sociologists are concerned with modernism as a historical period, often referred to as modernity. Modernism, for Bell, was anti-bourgeois, and co-existed with the bourgeois world view typical of modernity as long as it remained limited to aesthetic production. Once the critical practice of aesthetic modernism was enacted in everyday life, the social order of modernity was undermined.

Drawing on Max Weber, Turner (1990) has argued that,

[m]odernity is ... the consequence of a process of modernization, by which the social world comes under the domination of asceticism, secularization, the universalistic claim of instrumental rationality, the differentiation of of the various spheres of the lifeworld, the bureaucratization of economic, political, and military practices, and the growing monetarization of values.(p.6)

According to Featherstone (1988), 
... to speak of postmodernity is to suggest an epochal shift or break from modernity involving the emergence of a new social totality with its own distinct organizing principles.(p.198)

As a consequence, sociologists set about analysing the changes in society resulting from movement from the industrial to the information age. Postmodernity is marked by the expansion of electronic means of communication as well as faster forms of transportation, changes in consumption and production. In effect, for those who possess the technology, the world becomes much smaller (Harvey, 1989). Drawing on the works of Marshall McLuhan, postmodernity is seen in terms of the emergence of a 'global village'. A sociological postmodernist might analyse the CBC's 'electronic town hall' as one of the most obvious expressions of this change in society.

It is important to distinguish aesthetic modernism from the sociological concept of modernity. Sociological modernity, and the related concept of postmodernity are descriptive terms used to designate social conditions. Aesthetic modernism and postmodernism refer to specific ways of doing art, in other words styles. Postmodernism in the arts is concerned with developing forms of aesthetic practice which subvert the stylistic of imperatives modernism. A sociologist may study the relation between the aethetic practices of postmodernism and the set of sociological conditions called postmodernity. but she or he does so using traditional sociological concepts 
Postmodern Social Psychology 31

and methods of inquiry. To employ the Kuhnian metaphor of paradigms, if modernism and postmodernism can be seen as distinct paradigms, then the sociology of postmodernity stays within the modern paradigm, but focuses on new phersomena within that paradigm. Aesthetic postmodernism, on the other hand, requires a shift in paradigms.

\section{General Postmodern Theory}

Whether one is talking about an aesthetic style or an historical period as postmodern, there has come to exist a more general sense of the term postmodernism which is no longer discipline specific. While enclaves within the arts and sociology may still harken back to contrasts between the modern and postmodern, recently a style of speaking about postmodernism which begins with postmodenrism in its own right has emerged.

When postmodernism is introduced in this very generalized way it usually bears the traces of the encounter between American postmodernism and French 'poststructuralism'. Writers will lump together as foundational of theoretical postmodernism a range of positions taken by Derrida, Foucault, Barthes, and Lyotard, the purported founders of postmodern theory. Often included are a set of 'accessory' thinkers, among them wittgenstein and Rorty in philosophic discussions, Jameson and Habermas in the arts, and Baudrillard and Deleuze in social theory. Notwithstanding the 
Postmodern Social Psychology 32

differences between all these individuals, generalized theories of postmodernism tend to present these differences as 'superficial' (Hekman 1990).

The difficulties with generalized postmodernist theory are numerous. Such a theory may serve to neutralize, obscure or misappropriate alternate theories within a discipline, like feminism or post-colonialism. These latter theories have had a radical disruptive potential which can be overlooked within a broader general postmodern theory. The conspicuous fact that the pantheon of postmodernist writers is almost exclusively male and white has not been overlooked (hooks, 1990; Morris, 1988). As Finn asks: "why are there no great women postmodernists?" (Finn, 1993). All the more reason to examine this further is the fact that many of the theoretical claims attributed to postmodernists have been anticipated by feminist writers, among them, the critique of the taken for granted-ness of identity, the problematization of consciousness, and the politicization of the local. Furthermore, postmodernism in this very generalized sense can be brought into a discipline leaving little change in the discipline. As sondi (1990) points out with respect to geography.

postmodernism is debated, or in some cases assimilated, within existing theoretical frameworks in ways that resist any fundamental challenge to existing 'radical' geography.(p. 156) 
Postmodern Social Psychology 33

I use the phrase 'General Postmodern Theory' to refer to accounts of postmodernism which are constructed on the basis of secondary sources, and which reduce the plurality of positions developed by a variable set of thinkers nominated as postmodernists to a set of first principles: among them the critique of foundational concepts, the argument that truth is grounded in perspectives, an emphasis on the language of theoretical discourse, and epistological relativism.

Two consequences result from this overgeneralization. First of all, it lends the authority of all of the thinkers comprising the selected 'postmodernists' to specific statements which are attributed to them as a group. Secondly, it allows critics to dismiss the 'postmodernists' as a group on the basis of weaknesses and contradictions in generalized secondary accounts. Both operations blunt the critical edge of the writings of those subsumed under the generalizing rubric 'postmodernist'.

General Postmodern Theory differs from aesthetic or sociological postmodernism in its evaluation of the concept of the postmodern. While the former schools of thought speak of the term with varying degrees of pessimism (Bel1, 1976; Etzioni, 1968; Jameson, 1984) or as a problem to be resolved (Kaplan, 1988), this more generalized view sees postmodernism as a fait accompli and approaches this new age with enthusiasm. Rosenthal (1993) argues;

[a]s it is brought to bear on the various academic 
disciplines (postmodern pedagogy, postmodern anthropology) postmodernism becomes celebratory and promotional. The postmodern theorist as hero is self-cast as a reckless transgressor of borders, laying waste to outmoded paradigms, while sensitive to difference as none before.(p.101)

General Postmodern Theory often fails to offer a critical analysis of modern thought, politics, and culture. According to Rosenthal,

. postmodern discourse has hardened into a set of
rhetorical conventions before postmodern social
theory had a chance to develop. The transformations
in social and economic life that underlie theories
of the postmodern, such as the new economies of
information, new global organizations of commodity
production, the impact of new technologies on work
life and the impact of just-in-time prcductior. on
job security as well as commodity consumption - all
of this continues to take shape around us,
continues to cry out for understanding. New work by
scholars and activists is still going forward, but
no longer goes forward under the rubric of
postmodernism.(p.104)

This pronouncement bodes ill for social psychology, where postmodernism has only recently entered into discussion.

As I shall attempt to show, the problems attendant to General Postmodern Theory emerge in social psychological discussions, thus making postmodernism an unlikely candidate for the resolution of the conceptual problems surrounding the individual and the social brought to light in the recurring crisis within the discipline. This does not mean that social psychologists have nothing to learn from postmodernism, but rather to point out some of the pitfalls involved in going postmodern. 
Postmodern Social Psychology 35

Part III: Postmodernism and Social Psychology

In the introduction to Deconstructing Social Psychology, editors Ian Parker and John Shotter (1990) argue,

[During the 1970's] social psychology appeared to be in the middle of à resolvable crisis. Now we realize the problems were more deeply rooted. For the crisis is not to be found just in theories and assumptions of social psychology, but in whole sets of 'crises' to do wi:h the very character of the conduct of western intellectual ife (p.1)

The developnent of what John Morss (1992) called a 'second wave' of critical social psychology forms the basis of the introduction of postmodernism within social psychology. The second wave makes explicit reference to the first wave of criticism launched in the 1970s, and yet maintains a distance from it. The very title of Parker and Shotter's collection is a self conscious reference to a collection produced during the 1970 s entitled Reconstructing Social Psychology (Armistead, 1974). However, as the editors maintain

We need to press forward the critical dynamic which Reronstructing Social Psychology encouraged, and to draw upon contemporary theoretical debates to unravel the ways in which the very nature of our knowledge-producing practices and institutions entrap up, and lead us into simply reproducing unchanged what in fact we thought we were reconstructing (p.1).

It is this critical shift that has lead some social psychologists to engage with postmodernism.

While Parker and Shotter do not employ the term 
Postmodern Social Psychology 36 'postmodernism' in this collection (1990), other writers do, for example, Collier, Minton and Reynold's historical work Currents of Thought in American Social Psychology (1990) culminates in a discussion of 'social psychology in the postmodern age'. This is a rather emphatic pronouncement, considering that only a small number of psychologists, and even fewer social psychologists, have actually employed the term or attempted to examine the concept. Fur collier et al., the fact that those few discussions of postmodernism by social psychologists have occurred in the context of the new interpretive paradigm which grew out of the crisis of the 1970s, leads them to conclude that the new paradigm itself was ; part of a more general postmodern movement within western citure as a whole.

In order to more clearly examine postmodernism in the context of social psychology, I will examine specifis works linking postmodernism to social psychology. I have selected the works of Ken Gergen and Ian Parker for this purpose, because they have dealt with the concept of postmodernism most explicitly. Gergen and Parker also represent two different, although not distinct, intellectual traditions. Gergen, as I have already discussed, was part of the first wave of the new interpretive paradigm of social psychology, while Parker is a protagonist in the second wave of criticism. Gergen's encounter with postmodernism occurs within the context of American neo-pragmatism; Parker's is rooted in the British 
Postmodern Social Psychology 37

Left, heavily influenced by structural Marxism and psychoanalysis. A further reason for this choice is the critical exchanges between them over the nature of postmodernism. While other accounts do in fact exist, (HareMustin and Maracek, 1988; Collier, et al. 1990), the differences between Parker and Gergen form the conceptual terrain within which postmodernism is discussed in social psychology .

\section{Gergen's Postmodernism}

Gergen's most recent contributions to the critical literature in social psychology have been concerned with the introduction of postmodernism into psychological theory, as well as the extension of social constructionism to fields of study other than social psychology. What I will attempt to show are the developments which Jead from historical social psychology to postmodernism in Gergen's work. Gergen is a prolific writer and his accounts of postmodernism comprise only a small, though not unrelated, portion of his body of work.

In the late 1970 s Gergen provoked a significant debate over the nature of social psychological inquiry. Arguing that sucial interaction was historically contingent, he claimed that social psychology could not provide immutable laws of social behaviour (Gergen, 1973). Rather than being a scientific discipline, Gergen argued that social psychology 
was an historical mode of inquiry.

Science, according to Gergen (1973), involves 'the establishment of general laws through systematic observation.' (p.310) The natural sciences have been successful at this endeavour because natural phenomena are relatively stable, and therefore allow for the accumulation of knowledge. According to Gergen the 'facts of social psychology are non-repeatable and fluctuate markedly over time'(p.310). If this is the case then the use of scientific methods, which aim at uncovering transhistorical laws, is misguided. Thus 'knowledge canıot accumulate in the usual scientific sense because such knowledge does not generally transcend its historical boundaries.'(p.310) Rather than engage in a Quixotic attempt to discover universal principles, social psychologists should concern themselves with describing the particular processes operating at present.

Gergen's first critique of social psychology as science argues that the role of the scientist is to interpret seemingly meaningless phenomena in order to produce useful knowledge, which is then disseminated to the populace. This relationship is problematic for social scientists because the recipients of this knowledge are also the objects of study. The knowledge social psychologists produce can affect the nature of the phenomena they study. Thus the social scientist and society constitute a 'feedback loop'. Gergen argues that this feedback loop can affect psychological research in three 
ways: it can set up or maintain existing evaluations, it can supply subjects with information which can free them from the effects of psychological processes, and it can foster resentment towards principles which may be used for the purposes of social control. Each of these factors can alter the behaviour of research subjects, and therefore invalidate existing theories.

Gergen's sicond line of argument is concerned with the issue of transhistorical laws. Gergen points out few social psychological theories have withstood the test of time. He attributes this lack of durability to the inherenty historical nature of social interaction. As Gergen puts it,

In essence the study of social psychology is primarily an historical undertaking. We are essentially engaged in a systematic account of contemporary affairs. We utilize scientific nethodology, but the results are not scientifi:= principles in the traditional sense.' (p.316-317)

While experimental methods may provide researchers with results, these results cannot be generalized to all people. since one necessary condition for a scientific theory is universality, psychological knowledge is not scientific.

Gergen draws five implications from his social psychology as history thesis. The first implication is an integration of the pure and applied. If social scientific knowledge is historically bound, then the search for universal principles is chimerical, and therefore of little use for sorial change. 
Postmodern Social Psychology 40 According to Gergen social psychology should concern itself with the rigorous study of contemporary social issues.

Secondly, Gergen claims social psychological theories can serve as sensitizing devices which will enlighten individuals to the range of forces which may influence their behaviour. A third implication is that social psychologists may also apply themselves to the measurement of psycho-social dispositions at particular periods. In other words, we may avail ourselves to the task of descriping 'prevailing norms'.

The fourth implication ties in with Gergen's discussion of behavioral regularities. He argues that social psychologists can also describe durable patterns of social behaviour on a 'continuum of historical durability'. While it might seem that Gergen is trying to sneak 'universals' into his account of social psychology as history, it is important to note that the notion of durable calls the notion of universals into question. Seeming universals may simply be persisting regularities, relying on long-standing social conditions.

The final implication Gergen draws is a rapprochement between historical and social psychological research, in order to form an 'integrated social history'.

A feature of Gergen's latter theoretical work is the problematization of knowledge. If social interactions are historically conditioned, and knowledge is a social product, then the formation of knowledge is always subject to specific 
Postmodern Sccial Psychology 41

conditions of time and place. Gergen's social epistemology can therefore be seen as a refinement of his social-psychology as history thesis.

\section{Social Constructionism}

Gergen's social constructionism is a consequence of his rejection of the distinction between psychology and sociology, the term itself having been borrowed from Berger and Luckman's (1967) treatise of the sociology of knowledge. Berger and Luckman were primarily concerned, not with philosophical ideas, but rather with everyday knowledge. In effect, social constructionism would seem to provide a firm foundation for interpretive paradigms in social psychology.

According to Gerger. (1985), social constructionism is based on four inter-related claims. The first is riat

... what we take to be experience of the world does not in itself dictate the terms by which the world is understood. (p.266)

This is simply a restatement of the Kantian notion that the form of ideas is not derivable from brute experience alone. According to Kant (1988)

The understanding does not derive its laws a priori from, but rather prescribes them to, nature.(p.200)

For this reason I will call it the phenomenological thesis. What it points to is the active, constitutive role of the human subject in experience, as well as the constituted nature 
of objects of experience.

Social constructionism differs from kantian phenomenology because it does not assert that the a priori forms of consciousness are universal, but rather rooted in historical contingencies,

$$
\begin{aligned}
& \text {...the process of understanding is not } \\
& \text { automatically driven by the forces of nature, but } \\
& \text { is the result of an active, cooperative enterprise } \\
& \text { of persons in relationship. (Gergen } 1985, \text { p.267) }
\end{aligned}
$$

Or as Berger and Luckman (1967) put it; "...man's consciousness is determined by his social being"(p.6). This claim, which I will call the relational thesis, ties the process of understanding to interpersonal relationships, hence socializing consciousness. This claim breaks with Kantian phenomenology in that it locates the a priori of consciousness in the social rather in the individual mind.

If forms of understanding are rooted in social processes, then a third claim follows, namely that changes in forms of understanding are not

fundamentally dependent on the empirical validity of the perspective in question, but on the vicissitude of social processes (Gergen, 1985, p. 268)

This claim is a reformulation of Gergen's historical thesis. Finally, Gergen claims that

Descriptions and explanations of the world themselves constitute forms of social action. (Gergen 1985, p.268) 
Postmodern Social Psychology 43

This claim depends on a number of implicit arguments, primary of which is the idea that linguistic events constitute social processes in and of themselves. If this is the case, Gergen's third claim would mean that changes in descriptions and explanations would be sufficient to change forms of understanding, and therefore, of 'altering reality'. It is the relationship of thought to language which serves as the crux of Gergen's social constructionism.

The relation between language, social processes and realities serves as a basis for Gergen to approach postmodernism. As I have already indicated, Gergen has devoted only a small part of his theoretical corpus to postmodernism, and of these writings only one essay is concerned with social psychology proper. His most recent book, The Saturated Self (Gergen, 1991), offers a somewhat lengthier account of postmodernism, although it is not specifically concerned with psychology. It does offer a background for his social psychological works, and indeed, is indebted to them.

Gergen argues that modern thought is exemplified by, or rather culminates in, logical positivism. Gergen notes that there are many moves away from empirical science as described by logical empiricism, including; constructivists, constructionists, phenomenologists, hermeneuticists, ecological psychologists, ethnogenicists, and discourse analysts. According to Gergen (1990), 
Postmodern Social Psychology 44

...these are related departures, and they are not unique to the discipline of psychology. Essentially they are constituents of a much larger and more profound range of intellectual and cultural transformations. They are constituents of what many now view as the postmodern turn.(p.24)

Putting aside for the moment who the 'many' are, it seems that Gergen is implying that the postmodern turn is a large and profound range of intellectual and cultural transformations. For Gergen, experimental social psychologv is the expression of modernism within psychology. He states,

The psychological sciences were, to be sure, enthusiastic and able participants in the modernist romance.(p.25)

Gergen (1990) argues that there are four 'overarching presuppositions' which bear the traces of modernism. The first trace is the notion of a basic subject matter,

At the core of modernism lies the belief in a knowable world (p.25).

In the case of social psychology it is the individual and the group which form the basic subject matter of social psychology. As you will recall, the development of a scientific social psychology for Ross involved the separation of the individual and the social world.

The second presuppostion is the belief in universal properties:

..it is presumed that there are principles, possibly laws, that may be discovered about the properties of the subject matter.(p.25-26) 
Thus, laws of human interaction can be discovered. This harkens back directly to Floyd Allport's desires to develop a set of universal laws of social behaviour.

The basis for discovering psychological laws is the empirical method;

Following largely the rational justification of logical empiricist philosophy, modernist psychology has also been committed to a belief in truth through methods. (p.26)

The final trace of modernism in psychology is the belief that research is progressive;

Derivative of the preceding assumptions is the final modernist belief, a belief in the progressive nature of research. As Empirical methods are applied to the subject matter of psychology, we can learn increasingly about its fundamental character. False beliefs can be abandoned, and we move toward the establishment of reliable, value neutral truths about our designated segment of the objective world. (p.26)

At this point it seems that Gergen has just dressed-up his own criticisms of experimentation in postmodern garb. There is some support for this suspicion as he has employed the rhetoric of 'larger and more profound movements' prior to his proclamation of the 'postmodern turn'.

...many now recognize clouds of threatening demeanour gathering on the horizon. These ominous vapors are varyingly labelled post-structuralist, post-empiricist, post-modern, interpretive, constructionist, and hermeneutic. And while these orientations are not identical they do share certain underlying affinities that lend to them a unifying power. (Gergen 1989, p.239) 
Postmodern Social Psychology 46

of what exactly does this unifying power consist? First of all, it provides a sense of support by numbers. After all, who would have the audacity to contradict the collective insight of the above groups?

Secondly, it hints at a deeper level of agreement than in fact exists. Since these tendencies have such diverse origins, it would seem that agreement among them must portend something of significance. 'This emergence of postmodern consciousness within the academic sphere' he claims (Gergen, 1990), 'is only a sign of social change of much greater proportion'(p.112).

Gergen's account of postmodernism rests on what I described earlier as General Postmodern Theory: the lumping together of theorists as if they represented a coherent and unified framework of thought. For Gergen, the sociological form of postmodernism is the outcome of historical transformations, specifically in the area of communication and transportation technologies. His thesis in The Saturated Self is that these technologies increase the degree of relation between people to the extent that the boundaries between self and other have become less solid. According to Gergen (1991)

...we have become increasingly populated with fragments of the other, each of harbouring expanded congeries of potentials for relating and replacing the other.... The postmodern being is a restless nomad. (p.172-73)

Yet Gergen's postmodern nomad has much more in common with the tourist than the desert wanderer. Moore (1988) argues that 
Postmodern Social Psychology 47

this 'population by pieces of the other' has insidious implications,

These days it is much easier for all of us to travel - through strange places and other cultures. We try to be polite to the 'natives' and then return with anecdotes about how well we got on with the people. No, we weren't like those other tourists, we really got the feel of the place. We buy a piece of 'otherness' and bring it home to put on the mantlepiece. We didn't steal it, we bargained for it in the marketplace ... in their language. We were $k$ ind and cautious. Colonization is a cruel word for such harmless holidays.

Yet the whole point about going on holidays is that you know you are coming back. You may be another person while you are away. You may feel different but that is because your identity is firmly established elsewhere.(p.167)

This description is remarka" 'y similar to Gergen's account of the 'reflexive dialogical approach' to research, (Gergen \& Gergen, 1991)

The foremost feature of this type of work is the sharing of power between researcher and subjects in order to construct meaning. 'Subjects' becomes 'participants', and the number of interpretations (or theoretical possibilities) generated by the research is expanded rather than frozen.(p.86)

By a shift of terminology, the researcher is put on par with the 'participants', and yet the researcher, like the tourist. is leaving her or his own conditions and entering that of the 'natives', to capture a bit of the other. Gergen fails to address the power differentials involved in social inquiry, which are similar to those involved in tourism.

While Gergen is concerned with the development of 
Postmodern Social Psychology 48

interpretive methods and the study of narrative by social psychologists, it is worthy of consideration that it is precisely these processes which have come under critical analysis by literary 'postmodernists'. Sontag, for example, has called into question the very process of interpretation, arguing in favour of an affective relation to art. According to Sontag (1982)

Real art has the capacity to make us nervous. By reducing the work of art to its content and then interpreting that, one tames the work of art. Interpretation makes art manageable, comfortable. (p.99)

Literary postmodernism points to the incapacity of the analytics of narration or interpretation to represent or comprehend human existence. To lay these forms upon 'everyday viderstandings' is contrary to the spirit of literary postmodernism. One can remain very much within the modern tradition and do the kind of interpretive work that Gergen is suggesting. Meaning seen as conveyed through language, and for Gergen understanding occurs in conversation and shared meanings.

As wh have seen, Gergen's use of postmodernism falls into the trap if general postmodern theory, reducing the claims of postmodernism to his own version of social constructionism. Gergen's postmodernism provides little basis for political action, but rather relies on a rather lame appeal to a plurality of narratives. This claim rests on the assumption 
Postmodern Social Psychology 49

that changes in analytic frameworks are themselves forms of social action, and therefore sufficient for social change. We must here take stock of what Gergen means by the term 'social'.

Gergen, like Ross and Allport, reduces the social to the mental interrelations between human beings. The social does not however correspond to the political; in fact, Gergen's theoretical writings are profoundly anti-political, and thus are consistent with the historical underpinnings of social psychology. Gergen seems to imply that the social is in effect the product of common discourse (talking together that is) among distinct, if socially embedded, entities. In Gergen's account, power never assumes a concrete or material form. Any inequities are due to the stories we tell, never because of who owns resources, who has to pay to use them, who profits from those who labour, and who has access to public goods.

Gergen's solution to the individual/social problematic is to reduce psychological phenomena to social processes. Gergen (1985) argues,

When the implications of [social constructionism] are fully elaborated, it becomes apparent that the study of social processes could become generic for understanding the nature of knowledge itself. Social psychology would not stand, in this case, as a derivative of general psychology. Rather, the latter would be viewed as a from of social process, both the grounds and outcomes of which stand to be elucidated by social inquiry.(p.266)

Where Allport reduced social psychological phenomena to the 
Postmodern Social Psychology 50 individual, Gergen repolarizes the dichotomy between the indvidual and the social in the direction of the social. He does not call the dichotomy into question.

Gergen's work has provided a basis for the development of marginal, or at least unconventional, research within social psychology, and has provided a basis for continuing debate. Yet Gergen's social constructionism and the attendant pluralism he continues to propound does little to serve critical ends. If, as Gergen argues, all forms of social psychology are stories, then one must conceed that social constructionism and experimentalism can co-exist peacefully as different, but equally valid stories. The conciliatory tone of much of Gergen's later works can in part be seen as an attempt to "mainstream" social constructionism, at least for the role of the loyal opposition. One must wonder at what cost does the marginal go mainstream? Gergen's global use of notions like postmodernism, evident in the celebratory tone of his recent works on the subject, give the impression of resolving longstanding theoretical and political conflicts within social psychology. Gergen seems to have forgotten the critical intent behind his early work, and if anything, this should make us suspicious of his attempt to postmodernize social psychology. The critique of experimental social psychology is not simply a matter of taste, but rather based on the reasoned conviction that there is something conceptually, ethically, and politically wrong with both the theory and the practice of 
Postmodern Social Psychology 51

experimentation applied to human action. All of these possibilities have been cogently argued by theorists writing since the 1970s (Elms; 1975; Ring, 1967; early Gergen, 1973).

\section{Parker's Ambivalent Postmodernism}

While Gergen's work has often been subject to criticism from experimentalists and adherents to the psychological version of logical positivism (Schlenker, 1976), another form of critique has emerged from within the paradigm of alternative social psychologies. As introduced earlier, Morss (1992) describes this development as a second wave, drawing on the crisis literature of the $1970 \mathrm{~s}$ yet critical of it and the solutions offered. According to Morss, the second wave developed in the 1980s, in part as a response to the formalization of the first wave in social constructionism, a development which made the new interpetive paradigm less open to 'wider intellectual influences'(p.446). As Morss (1992) argues on behalf of developmental psychology (but no less true of social psychology)

The second wave was responding to the first wave, which it treated as somewhat inadequate, as much as to the still on-going orthodoxy in developmental psychology. In collections such as changing the subject (Henriques et al.. 1984) and Critical Theories of Psychological Development (Broughton, $1987)$ there are appeals to such social science and philosophical movements as neo-Marxigt theory (Althusser) and other social-critical analyses (Adorno, Habermas), and to poststructuralist thinking, especially Foucault. (p.446)

While the first wave belonged to American social 
Postmodern Social Psychology 52

psychologists, the second wave is almost exclusively comprised of British developmental psychologists. The difference in terms of intellectual traditions is significant, especially in terms of politics. The first wave tends to espouse a form of liberal humanism, asserting the fundamental similarity of human beings in a common humanity; it appeals to an abstract pluralism which defends the unassailable validity of any and all world views. The English Marxist tradition, on the other hand, revolves around notions of class, ideology, and conflict, greatly influenced by Althusser's 'structural' Marxism.

While Morss is specifically concerned with developmental psychology, he does list a number of social psychologists among the second wave, among them Ian Parker. Parker, like Gergen, has discussed postmodernism in relation to social psychology, although in a much more guarded manner. Unlike Gergen, and most North American social psychological approaches to postmodernism, Parker consistently poses postmodernism as a problem for social psychology, not a solution to its 1lls. In the following section I will discuss Parker's account of postmodernism as he deselops it in two of his main works, The Crisis in social psychology, and How to End It (1989), and Discourse Dynamics (1992a).

In contrast to Gergen's apparently enthusiastic embracing of postmodernism, Parker offers more ambivalent treatment of the subject. While initially appealing to a notion of 
Postmodern Social Psychology 53

postmodernism as a historical era (Parker, 1989), he has moved towards a critical engagement with postmodern theory. It is clear that he recognizes the ambiguous use of the term, thus avoiding the conflation of the term with what he calls the 'watered-down poststructuralism' (Parker, 1992a, r.74), which has appeared in social psychology (eg. Hare-Mustin \& Marecek, 1988). Aware of the distinction between aesthetic and sociological postmodernism, Parker argues that the former holds more promise for social psychology than the latter (Parker, 1992b). According to Parker (1992a),

There is, strictly speaking, no such thing as
postmodernity. There are, rather, pockets of
contemporary culture in which it is possible to
identify postmodern themes, and for which the
postmodern condition may be'true'. We have to take
care to distinguish the collapse of the modern
project in sectors of academic life and avant-garde
culture from the delusional projections of that
postmodern condition onto the whole of society.
(p.72)

For Parker these 'pockets of postmodernism' can serve a critical function, specifically in the context of discourse analysis.

Parker defines three orders of social life: the practical, the expressive, and the political. Drawing on the works of critical realist Rom Harré, he argues that the practical order is the field of material objects and practices, such as cars or freeways, and driving. Objecus in the practical order are mediated through the expressive order, within which they become objects of discourse or knowledge; 
Postmodern Social Psychology 54 for example, traffic reports. Unlike Harré, Parker maintains that there is also a political order which cuts across both the expressive and the practical orders. Invoking the concept of ideology, he argues that the political order has both discursive and practical dimensions: ideology is not just a synonym for a belief system, but is iled to material objects and practices for example, where freeways are built.

Parker (1992b) argues that postmodernism "is tactically useful as a way of disrupting theories, opening up conflicts" (p.82). However, he is reluctant to adopt postmodernism uncritically since he sees it as primarily concerned with discourse, or in his schematization, the expressive order. According to Parker, postmodernism grounds critical practice solely in reflexivity, thus neglecting material conditions; for example, the plight of the homeless. In other words, the practical order is disregarded in favour of the expressive. For Parker (1992b) the danger of postmodernizing social psychology is a lapse into cultural relativism and a depoliticised reflexivity, one which "merely dissolves our experiences in a plurality of different perspectives..." (pp.77-78). The plight of the homeless therefore becomes secondary to discussions analysing the problem of homelessness.

Parker (1992b) recognizes that the resolution of the individual-social dichotomy is the basis of social psychology. He writes, 
social psychology is founded on the premise that the gulf between the individual ard the social can be bridged. Social psychology is supposed to be that bridge, but it is not. (p.90)

Parker argues that there are two ways in which the gap between the terms can be bridged: through politics and through reflexivity. He is critical of the effort to bridge the gap through reflexivity, which he argues was the intent of the fist wave of criticism emerging out of the crisis of the 1970s;

A fundamental premise of the new social psychology, a 'new paradigm' to rescue trie discipline, was that the space between the disciplines of the individual and the disciplines of the scicial could be filled with a more sophisticated theory.(p.91)

Reflexivity, the practice of self-critical inquiry, he claims, is problematic, because one is all too easily led into the trap of assuming that it is the solution to the methodological misgivings of critical social psychologists. It is not sufficient to merely say one is reflecting on one's own research biases, since to expose one's preconceptions one has to have some idea about which preconceptions are salient in the research piocess. In addition, merely forming a list of preconceptions does not purge my work of their effects.

Parker (1992b) is emphatic though that the use of reflexivity in place of politics is a dangerous tendency in the 'new social psychologies':

There is something odd going on when the connection 
Postmcar Social Psychology 56

between the individual and the social is made in terms of 'reflexiv $t y$ ' instead of political practice. (p.92)

It is clear that what is absent from reflexive psychology is that it attends too much to what psychologists say, and too little to what psychologists do.

According to Parker the gap between the individual and the social can also be bridged through practice. While postmodernism may be useful for opening up conflict, it is only though action that political effects are produced. In place of reflexivity, Parker argues for ideological analysis. Dismissing the tendency to reduce the concept of ideology to biases, he sees ideology as both symbolic, or discursive, and material, or practical. Critical social psychology would therefore become a form of ideological analysis, one which looks both at what social psychologists say and do. In any event, Parker does not see the role of critical social psychology to be the resolution of the crisis in social psychology, but rather its attenuation. Parker (1992b) writes,

We should not aim to improve the discipline, but to continue the crisis in social psychology so that there will always be room for manoeuvre. (p.94)

\section{Sumary}

After reviewing both Gergen and Parker's writings on postmodernism and social psychology, I would conclude the following: For Gergen, experimentation is the quintessential expression of modern social psychology. Gergen uses 
Postmodern Social Psychology 57 postmodernism to describe a shift from experimentation to interpretation as the proper direction for social psychology. Interpretation is part of a much larger set of intellectual and cultural transformations for Gergen. Parker would claim that interpretation as well as experimentation are fart of modern social inquiry. They are different techniques for getting at human relations. The shift from one method to another is still aimed at discovering underlying truths about the social world. Gergen's use of postmodernism is very much in the sense that I have defined as general postmodern theory, a lumping together of many intellectual directions which have emerged in the 1960s. Parker's use of the term postmodernism remains more closely connected to aesthetic postmodernism, that is as a critical tool.

In terms of the distinction made between the individual and the social world, the postmodern turn for Gergen means that the individual is now living in a new age, a new historical period. A person is saturated with relations so that the boundary between oneself and others blurs to the point where the individual is comprised of pieces of the other. Gergen suggests that social psychology focuses on linguistic relations between people rather than individuals taken on their own and separate from an objective social world. While it is true for Gergen that the modern distinction between the individual and the social collapses in the direction of social relations, there is still the need to have 
Postmodern Social Psychology 58

individuals as creators/constructors of their own social worlds. In so far as Gergen attempts to escape into the social, the individual still precedes the social world thereby reproducing the tension between the two. Because the social world is seen as purely mental interactions mediated through language, Gergen does not include in his analysis power and/or material relations that have an impact on defining individuals and their interactions.

In sum, postmodernism for Gergen serves a rhetorical end, namely to promote social constructionism as not only better than experimental social psychology but also as more suited to the times. The critical potential of postmodernism is missing. For Parker, postmodernism is a useful critical device in intellectual work but it is not an explanatory grand theory. Whereas for Gergen postmodernism is a solution, for Parker it is a way of raising questions. Parker does not see postmodernism as a universal, or even a predominant cultural form, but descriptive of a range of specific practices and discourses. Unlike Gergen, Parker does not point to experimentalism as the expression of modernism in social psychology, but rather retains the position that social psychology is a modern form of social inquiry. This means that interpretive social psychology cannot assume the place of the 'postmodern' in the discipline, but rather belongs within the space of the social psychological, which is precisely the space between the individual and the social. Parker is more 
Postmodern Social Psychology 59

interested in promoting a political understanding o- the social world.

While I feel Parker's work offers a sophisticated account of postmodernism, as well as arguing for the politicization of a discipline which has been historically resistant to political theorizing, his works still retain some of the overgeneralizing tendencies of what I have called General Postmodern Theory, in that he conflates the claims of a number of writers to a theoretical postion. Although he does refer to specific works, he does so in relation to analyses of discourse, which he understands as the focus of powstmodernism. For this reason, he does not draw out the implications of the works of the 'postmodernists' for the practice of social psychology.

I will argue, along with Rosenthal (1993), that postmodernism no longer has the power to unify the critical projects it is used to encompass, but rather that the sritical projects have proceeded in various directions, no longer under the rubric of postmodernism. Abandoning postmodernism should not lead to abandoning the works of Postmodernists, nor the project of critically examining the interconnections between modern political formations, culture, and philosophy. Rathis what is needed is to perform an exorcism of their works in order to free them of the demon of General Postmodern Theory. In short, we should save the Postmodernists from postmodernism. As Curry (1991) argues 
Postmodern Social Psychology 60

Postmodernists [geographers employing postmodernism] might have better understood their own failure to transcend modernist views if they had paid stricter attention to the views of those intellectual authorities whose works they claimed to underlie postmodernist works. (p. 211)

To this end, I will turn to the work of Michel Foucault, one of the postmodern elect who has received some degree of consideration by social psychologists, albeit under the analytic of postmodernism. 
Postmodern Social Psychology 61

Part IV: Foucault and Social Psychology: Towards a Politicized Social Psychology

Both Gergen and Parker ultimately retain the individualsocial dichotomy as the basis for a more "social" social psychology. I want to argue for a critical social psychology that politicizes and questions practices that make up 'the individual' and the 'social'. To argue this alternative, I will employ the works of Michel Foucault, which I feel provide the basis for a critique of the social and the individual in the terms I've suggested. Gergen rarely references Foucault while Parker sees Foucault's analysis as limited to language, to "discourse about discourse" (1992a). As such, his work is anathema to politically engaged social research. While I agree with Parker's criticism that political critique cannot be limited to discussion only, I feel Parker overlooked Foucault's substantial discussions of practice (1984). I will argue that Foucault offers a means by which a political understanding of the relationship between the individual and the social can be derived. While he does his work through critique of modern practices, there is no easy sense in which this makes him a postmodernist.

Foucault has been taken as a postmodernist by many (Turner, 1990; Featherstone, 1988) even if his own writings on the subject reveal ctherwise. For example, Foucault (1984) distances himself from postmodernism in his essay, 'What is 
Postmodern Social Psychology 6?

Enlightenment?' by criticizing the way in which historical perlods are characterized in overgeneral torms. He writes

Rather than seeking to distinguish the "modern era" from the "pre-modern" or "post-modern," I think it would be more useful t? try to find how the attitude of modernity ever since its formation has found itself struggling with attitudes of "countermodernity". (p. 39)

For Foucault, at any particular historical period there are critiques of that period from within and one does not need post-modernism as a way of standing outside modernity in order to critique it. Just as there has been, since social psychology's beginnings, a critique of how best to study social life, so Foucault makes the argument that there have always been critiques of modernity or the present. When asked about his reiation to postmodernism, Foucault argued against dividing history into eras in some nostalgic way. of this he writes

I think that there is a widespread and facile tendency, which one should combat, to designate that which has just occurred as the prinary enemy, as if this were always the principal form of oppression from which one had to liberate oneself. (p. 248)

While Foucault did not like the label of postmodernist, in the most general sense in which postmodernism is a critique of modern traditions his ideas may be helpful.

To understand Foucalil's political critique in a way that might be useful to social psychology, it is important to 
Postmodern Social Psychology 63 explore the history of how the meanings of 'individual' and 'social' have changed and are used by modern social psychologists.

The Individual and the Social in Political Context Contemporary use of 'individual' tends to define the individual as a private person, someone who exists as a distinct entity. The ancients had some sense of this usage, however, their meaning was distinct from modern notions. The Latin root of trie word, individuus, can be translated as 'unsplitable' or 'undjvidable', etymolocically similar to the Greek work atom. Neither of these terms was used to denote individuals in the contemporary sense of private persons. The Greek term ideo, the root of words like idiosyncratic or ideology, was used to refer to 'private persons'. However, the word had derogatory connotations for the Gi eeks, apparent in another of its English derivatives: idiot (Webster, 1965). Etymologically, the word 'social' is derived from the word socius, which refers to a companion or a partner or the property of holding something in common (Webster, 1965). A social relation would thus be one of partnership or companionship, a sinse maintained in the English colloquialism 'sociable'. Socius is also the root of the term society. The terms society and social were coined in the 16 th century. The Encyclopedie (1751-1772) defined the term 'social' as

a word newly introduced into the language lfrench, from 
which the english term was derived] to designate those attributes that render a man useful in society and $f$ it him for human intercourse (cited in R. Aron, 1968, p.7).

Being social made us $f$ it for life in society.

The modern usage of the terms 'individual', to connote private person, and 'social', to connote sociable relations, is echoed in the wricings of modern social psychologists such as Floyd Allport and E.A. Ross.

Floyd filport's definition of social behaviour echoes the definition of the Encyclopedie,

Social behaviour comprises the situations and reactions arising between an individual and the social portion of his environment; that is, between the individual and his fellows (1924, p.3).

Fo: Allport there is a private person who enters the realm of the social but is separate from it. Socialization is the process by which the individual becomes a part of society. Social life is described by Ross and Allport as mental contacts or interactions divorced from material conditions. The terms are not used in a political context. In fact, through the extension of mental interactions to non-human organisms as found in the writings of Ross (1908), McDougall (1908) and Murphy, Murphy \& Newcomb (1937) the 'individual' and the 'social' become natural'zed or biologized in social psychology. Ross (1908, p.1), in particular, argues that natural capacities become socialized, allowing a person to become more integrated in society. Th1s is very close to the 
Postmodern Social Psychology 65 idea of the Encyclopedie of the 18 th century that maintained that the social dimension for a man concerned those attributes which, 'render a man useful in society, and fit him for human intercourse.' (cited in Aron, 1968, p.7).

In its earlier usages, what we might now think of as the social would have been a form of politics, that is the way in which people get together and organize their common interests and reconcile differences of interest. Furthermore, earlier notions would not describe a split between the individual and the social as essential to understanding and being in the world. What has occurred is that the political dimensions of the social and the individual have become obscured in social psychology, and modern thought more generally, to the extent that they are understood as descriptors of natural phenomena. Social phenomena in social psychology are often treated as universals rather than culture-specific actions that could be otherwise. By looking for the equivalent of universal natural laws of social behaviour, as has happened in modern social psychology, political conflict is deligitimized. Conflict is seen as a dysfunction of social systems rather than integral to communal life.

Foucault and the Analysis of Power Relations

Foucault's notion of power serves to repoliticize social psycholog! without reifying the individual or the social. His approach allows us to see the discipline of social psychology 
Postmodern Social Psychology 66

with conflict as constant foreground rather than repetitive crisis. For Foucault, the meaning of power lies in the verb sense of the French "pouvoir", 'to be able to' or "to have the capacity to do'. According to Foucault (1984)

what defines a relationship of power is that it is a mode of action which does not act directly and immediately on others. Instead it acts upon their actions: an action upon an action, on existing actions or on those which may arise in the present or the future.... It is a total structure of actions; it incites, it induces, it seduces, it makes easier or more difficult; in the extreme it constrains or forbids absolutely; it is nevertheless always a way of acting upon and acting subject or acting subjects by virtue of their acting or being capable of action.... The exercise of power consists in guiding the possibility of conduct and putting in order the possible outcome. ( pp. 220-221)

Foucault argues that power is not a substance; it cannot be held or acquired. It is a property of relations rather than being outside of them. Unlike models of State power, Foucault argues that power comes from below the level of formal institutions. This entails that forms of relations, for example, philanthropic or self-help groups, are not free of the effects of power. Power influences actions directly, not via any conscious reflection on power. Foucault's ideas break down the distinction between public and private domains such that private life is also replete with power relations. Power does not operate by rewarding behaviour but rather it structures the field of possible actions. Finally, power for Foucault does not exist without resistance. This final point 
is central to his analysis. In many social relations power is exercised with the assumption that choices of action are available to the actors. He (1984) writes

Power is exercised only over free subjects, and only in so far as they are free. By this we mean individual or collective subjects who are faced with a field of possibilities in which several ways of behaving, several reactions and diverse comportments may be realized. Where the determining factors saturate the whole, there is no relationship of power; slavery is not a power relationship when man is in chains (p. 221).

For Foucault, there is no 'individual' or 'social' in the abstract but only relationships between people formed by strategies of power. If his analysis were taken into social psychology, one would not experiment and find differences among populations or survey respondents' attitudes as much as one would look for and identify sites of resistance to strategies of power. Take, for example, our understanding of the design of shopping malls.

Foucault would see the mall is a social or cultural technique aimed at getting people to buy; however by providing the technique, one also encourages resistance. This is sometimes referred to as loitering depending on who is meeting, for example, teenagers, the elderly, the homeless, etc. In Foucault's terms, loitering is a form of resistance to the imperative of shopping, as well as the privatization of public spaces. Loitering runs counter to the aims of the mall; it can create greater maintenance costs and it can detract buyers from going to the mall. Architects of shopping 
Postmodern Social Psychology 68

malls handle this situation by eliminating most places where loiterers might congregate. They tend to design in barriers to loitering through the use of steps, planters and the restriction of seating to a small area, specifically the food courts (where one might still buy) and bus stops, (where it is no longer a problem for the mall), and both of which are usually occupied by 'legitimate shoppers'. These are strategies of power because they operate on the basis of managing resistances, rather than eliminating them completely. While physically removing loiterers is one solution, it can be costly and inefficient as well as lead to legal complications for the mall owners. It is risky because one can be both a customer and a loiterer and the identification of the practice of loitering may not differentiate between the two, leading to a loss of revenue. For there to be two sets of diverging social practice in one place is not uncommon and in Foucault's sense social relations are managed through strategies of power. For Foucault, the mall would be seen as a social or cultural technique aimed at getting people to buy; however by providing the technique, one also encourages resistance.

The analysis that Foucault offers differs substantially from mainstream social psychology. The latter would survey attitudes, experiment with and observe the interactions between individuals in malls. Much of the aim would be to look at the impact of variables on buying or loitering behaviour. Gezgen $m$. ght examine the narratives produced by 
Postmodern Social Psychology 69

mall loiterers that constructs the meaning the mall holds for them. Parker would likely look at malls and critique their ideology from the perspective of the underclass, the loiterers. With Foucault, one would examine the conflicting interests of those with something at stake - mall owners, store merchants, shoppers and loiterers among others.

This type of analysis is what is meant by the politicization of social psychology. In fact, Foucault would take social psychology itself as practised in the mainstream and see it as a social and cultural technique of power. It promotes a sense of self as individual rather than interdependent and it forms social relations in ways that make power and conflict dysfunctional. Sites of resistance to the practice of social psychology can be found in the noncompliance of experimental participants, writing in the margins on surveys, and challenging researchers results that produce sexist and racist knowledge couched in scientific sounding biological determinism.

I would use Foucault to argue that a politicized social psychology would avoid the opposition of the individual and the social that ultimately robs relations of their contestable dimension. Furthermore, a politicized social psychology would not avoid an examination of the concrete interests at stake both in research and thesretical writings. Foucault's writings give rise to a political anti-psychology, one which serves to undo both what social psychologists do and 
Postmodern Social Psychology 70

what they say. In the end, political critiques would push crises to the limit, at which even the continued existence of social psychology is called into question. Political issues cannot be reduced to 'social problems' requiring management. Rather, I take Foucault to mean that the researcher adopts a perpetual 'agonistic' stance to social psychological inquiry. The role of the social psychologist is defined more as a cultural critic than a social engineer.

In conclusion, postmodernism as understood by Gergen and Parker is unlikely to resolve social psychology's historical tension between the individual and the social. However, use of specific 'post-modern' theorists such as Foucault can reorient us to the political dynamics of this dichotomy. If we take foucault seriously, the practice of mainstream social psychology and its critical branches are called into question. Lest I be classified as destructively nihilistic, I would end with Foucault's (1991) own optimism:

And if I don't ever say what must be done, it isn't because I believe that there is nothing to be done, on the contrary, it is because I think that there are a thousand things to do, to invent, to forge, on the part of those who, recognizing the relations of power in which they're implicated, have decided to resist or escape them. From this point of view all of my investigations rest on a postulate of absolute optimism. I do not conduct my analyses in order to say: this is how things are, look how trapped you are. I say certain things only to the extent to which I see them as capable of permitting the transformation of reality (p. 174). 
Postmodern Social Psychology 71 Referencess

Allport, F.W.(1924) Social Psychology. Boston: Houghton Mifflin.

Allport, G. (1954) The Historical Background of Modern Social Psychology. In G. Lindzey (Ed.), Handbook of Social Psychology (1st ed.). Vol. 1. Reading MA: Addison-Wesley. Armistead, N. (Ed)(1974) Reconstructing Social Psychology. Baltimore: Penguin.

Aronson, E., \& Carlsmith,J.M. (1954) Experimentation in Social Psychology. In G. Lindzey (Ed.), Handbook of Social Psychology (1st ed.). Vol. 1. Reading MA:Addison-Wesley. Baynes, K., Bohma, J. McCarthy, T.(1987) After Philosophy: End or Transformation? Cambridge: MIT Press.

Baudrillard, J.(1987) Modernity Canadian Journal of Political and Social Theory, 11(3), 63-72.

Bauman, 2. (198B) Is there a Postmodern Sociology? Theorv, Culture, and society, 5, 217-37.

Bell, D.(1976) The Cultural Contraditions of Capitalism.

New York:Basic Books.

Berger, P.L., Luckman T.(1967) The Social Construction of Reality New York: Anchor.

Berman, M. (1988) All That is Solid Melts Into Air Toronto: Penguin.

Bondi, L.(1990) Feminism, postmodernism, and geography: space for women? Antipode, 22(2), 156-167. 
Postmodern Social Psychology 72

Butler, J.(1992) Contingent Foundations: Feminism and the Question of "Postmodernism", in Feminists Theorize the Political, J. Butler and J.W. Scott (Eds), New York: Rout ledge.

Carty, A. Mair, J.(1990) Some Post-Modern Perspectives on Law and Society Journal of Law and Society, 17(4), 395-410.

Cheal, D. (1990) Authority and Incredulity: Sociology betweenb Modernism and Post-Modernism, Canadian Journal of Sociology / Cahiers Canadiens de sociologie 15(2), $129-147$.

Collier, G., Minton, H.L., \& Reynolds, G.(1991) Currents of Thought in American Social Psychology, New York: Oxford University Press.

Curry, M.R. (1991) Postmodernism, Language, and the Strains of Modernism. Annals of the Association of Ame: zan geographers, $81(2)$ 210-228.

Elms, A.C.(1975) The Crisis of Confidence in Social Psychology. American Psychologist, 30, 967-976.

Etzioni, A.(1968) The Active Society, New York:Free Press. Featherstone, M.(1988) In Pursuit of the Postmodern: An Introduction Theory, Culture \& society, 5, 195-215. Foucault, M.(1983) The Subject and Power, in Michel Foucault: Beyond structuralism and Hermanutics, 2nd ed. by H.L. Dreyfus \& P.Rabinow, Chicago: University of Chicago Press. 
Postmodern Social Psychology 73

Foucault, M.(1984) The Foucault Reader New York:Pantheon. Gergen, K.J.(1973) Social psychology as History Journal of Personality and Social Psychology 26, 309-32!.

Gergen, K.J.(1985) The Social Constructionist Movement i.i Modern Psychology American Psychologist 40, 266-275.

Gergen, K.J.(1990) Towards a Postmodern Psychology. Humanistic Psychologist 18(1), 23-34.

Gergen, K.J.(1991) The Saturated Self, New York: Basic Books. Gergen, K.J. \& Gergen M.M. (1991)' From Research to Reflexivity in Research Practice' in Research and Reflexivity, F. Steir ed. London:Sage.

Giddens, A.(1981) Modernism and Postmodernism New German Critique 22, 15-18.

Habermas, J.(1981) Modernity versus Postmodernity New German Critique $22,3-14$

Hare-Mustin, R. Marecek, J.(1988) The Meaning of Difference: Gender Theory, Postmodernism, and Psychology. American Psychologist, 43, 455-464.

Hare-Mustin, R. Marecek, J.(1989) Thinking about

Postmodernism and Gender Theory. American Psychologist, $44(10), 1333-i 334$.

Harvey, D. (1989) The Condition of Postmodernity: An Inquiry into the Origins of Social Change. London: Basil Blackwell.

Hassan, I. (1985) The Culture of Postmodernism Theory, Culture and society, 2(3), 119-132. 
Postmodern Social Psychology 74

Hekman, S.(1990) Gender and Knowledge: Elelements of Postmodern Feminism. Cambridge:Polity.

Hewitt, J.(1979) self and society (2nd ed) Toronto:Allyn \& Bacon.

hooks, b. (1990) Postmodern Blackness Postmodern Culture, 1 (1). (electronic publication, no page reference).

Huyssen, A.(1990) Mapping the Postmodern, in Feminism/

Postmodernism, L.J. Nicholson (Ed.) New York: Routledge.

Inkeles, A. (1966) what is sociology Toronto: Prentice-Hall.

Jameson, F. (1984) The Politics of Theory: Ideological

Positions in the Postmodernism Debate. New German Critique, 33.

Jencks, C.(1977) The Language of Postmodern Architecture.

London: Academy Editions.

Jones, E.E.(1985) Major Developments in Social Psychology

During the Last Five Decades. In G. Lindzey \&. Aronson (Eds.), Handbook of social psychology (3d ed.) vol.1. New York: Randon House.

Kant, I. (1988) Kant Selections, L.W. Beck ed. New York: Macailian.

Kaplan, E.A. (ed.)(1388) Postmodernism and its Discontents, London: Verso.

Klienberg, 0.(1940) Social Psychology New York: Henry Holt and Company.

Koehler, M. (1977) Postmodernism: A Survey of It's History and Meaning, Amerikastudien, 22, 8-18. (Thomas Austenfeld 
Postmodern Social Psychology 75

trans.)

Kroker, A., \& Cook, D. The Postmodern Scene: Excremental

Culture and Hyperaesthetics Montreal: New World Perspectives.

Letiche, H. (1990) Five Postmodezn Aphorisms for Trainers.

Special Issue: Postmodern Culture and Management Development. Management Education and Development, 21 (3) 229-240.

Levin, H. (1960) What was Modernism? Refractions, 227.

Lyotard, J-F. (1984) The Postmodern Condition: A Report on

Knowledge. Minneapolis: University of Minnesota Press.

McDougall, W. (1926) An Introduction to Social Psychology

(rev.ed.) Boston:J.M.Luce.

Moore, S.(1991) The Pimps of Postmodernism, in Male Order.

J. Rutterford ed. London:Lawrence.

Morris, M. (1988), The Pirate's Fiancée: Feminism, reading,

Postmodernism, New York:Verso.

Morss, J. (1992) Making Maves: Deconstruction and Social

Psychology, Theory and Psychology, 2(4).

Murphy, D.J.(1988) A History of Western Psychology. New

Jersey: Prentice Hall.

Murphy, G., Murphy, L.B., Newcomb, T.M. (1937). Experimental

Social Psychology. New York: Harper.

Newcomb, T. (1951) 'Social Psychological Theory: Integrating Individual and Social approaches' in Roher, J. Sherif, M. (eds) Social Psychology at the Crossroads. New York: 
Postmodern Social Psychology 76

Harper.

Newman, M. (1989) 'Revising Modernism, Representing

Postmodernism: Critical Discourses of the Visual Arts' in Postmodernism ICA Documents. L. Appignanesi (ed). London: Institute of Contemporary Art.

Parker, I.(1989) The Crisis in Mociern Psychology, and How to End It. Londion: Routledge.

Parker, (199.2a) Discourie Dynamics, London: Routledge

Parker. I.(1992b) 'Discourse discourse: Social Psychology and Postmodernity', in Postmodernism and the Social Sciences, J. Doherty, E. Graham, \& M. Malek (eds). New York:St. Martin's Press.

Parker, I., \& Shotter, J.(Eds.)(1990) Deconstructiong Social Psychology New York:Routledge.

Pytchel, T.A.(1988) Social Psychology's First "Crisis": An Historical Perspective of the Emergence of Experimental Social Psychology. Unpublished manuscript, Carleton University, ottawa, Ontario.

Ring, K.(1967) Experimental Social Psychology: Some Sober Questions about some Frivolous Values. Journal of Experimental Social Psychology, 3, 113-123.

Rosenthal, M. (1993) what was Postmodernism New Left Review. Ross, E.A. (1908) Social Psychology: An Outline and Source Book. New York: MacMillan.

Salaman, G. Butler, J.(1990) Why Managers won't Learn Management Education and Development 21(3) 183-191. 
Postmodern Social Psychology 77

Sampson, E.E.(1989) The Challenge of Social Change for

Psychology: Globalization and Psychology's Theory of the

Person American Psychologist 44(6) 914-921.

Schlenker, B. (1974) Social Psychology as Science. Journal of

Personality and Social Psychology, 29, 1-15.

Shapiro, G.(1990) After the Future, Albany: SUNY Press.

Shotter, J.,\& Gergen, K.J.(Eds).(1989). Texts of identity.

London: Sage.

Silverberg, J. \& Welton, D.(1990) Postmodernism and

Continental Philosophy, Albany: SUNY Press.

Soja, E.(1989) Postmodern G:ographies: The Reassertion of

Space in Critical Social Theory. London: Verso.

Sontag, S. (1982) A Susan Sontag Reader New York: Farrar,

strauss and Giroux.

Theodorson, G.A., \& Theodorson, A.G.(1969) A Modern D1ctionary of Sociology, New York: Barnes \& Noble.

Toynbee, A.(1947) A Study of History, New York: Oxford.

Triplett, N.(1898) The Dynamogenic Factors in Pacemaking and

Competition. American Journal of Psychology, 9, 507-533.

Turner, B. (Ed.)(1990) Theories of Modernity and Postmodernity

New York: Sage.

Webster's Seventh New Collegiate Dictionary, 1965. Toronto:

Thomas Allen. 

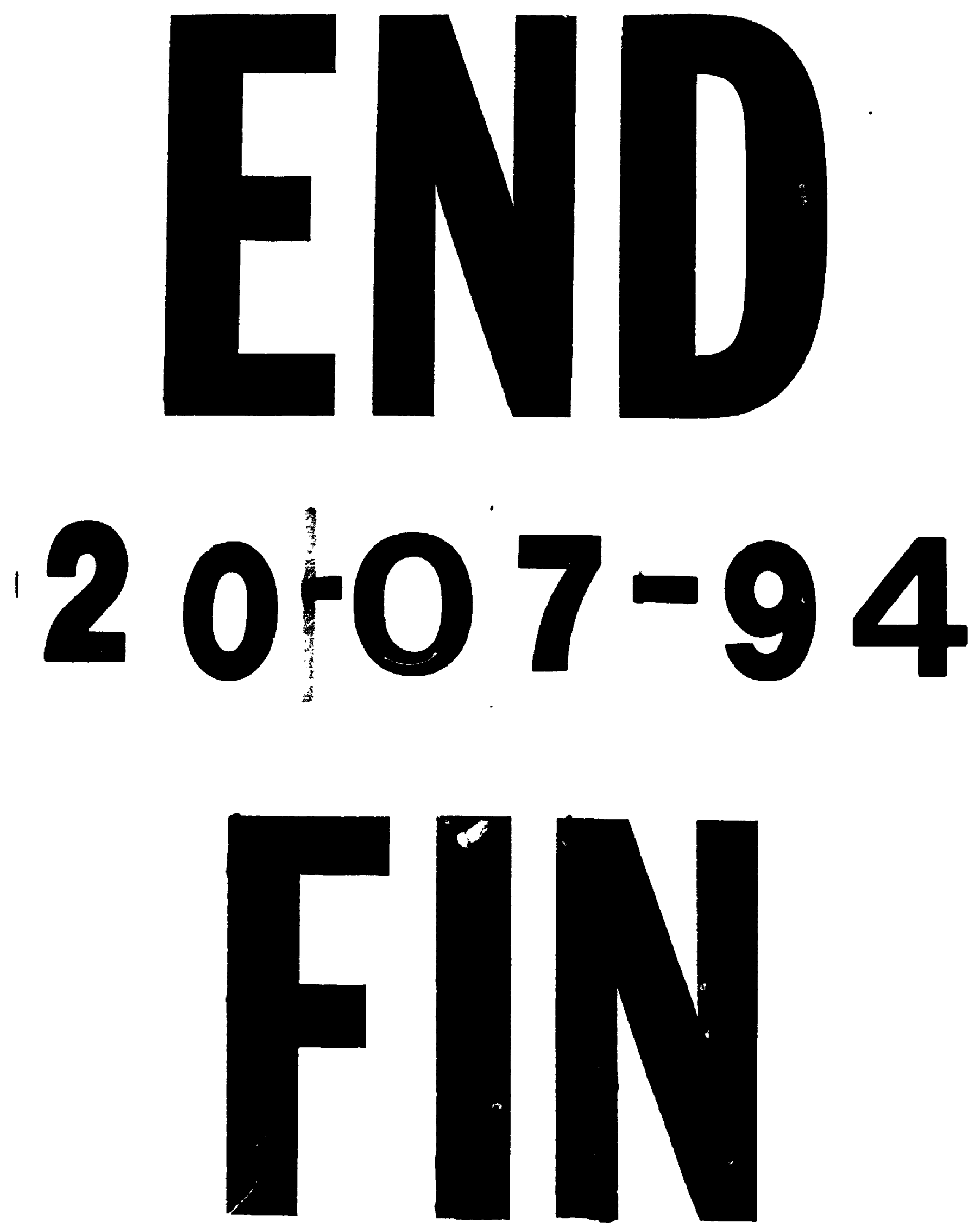